\title{
Introduction
}

\section{Peasant Insurgency and Guerrilla Radio in Northern Morazán, El Salvador}

\section{ERIK CHING}

WHAT FOLLOWS Is the story of a rebellion by poor peasants against the government of El Salvador and its benefactor, the United States. The peasant rebels were outgunned, outmanned, and outfinanced, and they ultimately failed to achieve their goal of overthrowing the Salvadoran state. But, remarkably, they fought the Salvadoran Army to a draw over eleven years of war (1981-1992), and they had enough bargaining power at the negotiating table to achieve some of their key objectives, including democratic reforms and an overhaul of the Salvadoran security forces.

The author of the memoir is Carlos Henríquez Consalvi, more commonly known by his nom de guerre, "Santiago." He was a central figure in El Salvador's civil war, although he was neither a peasant nor a Salvadoran. He was a Venezuelan who came to El Salvador to support the rebel cause and who lived and worked for the entire eleven years of war in the remote northeast of the country, in Morazán department.

Throughout the war, northern Morazán was the stronghold of the People's Revolutionary Army (Ejército Revolucionario del Pueblo, ERP). It was one of the five guerrilla factions that made up the Farabundo Martí Front for National Liberation (Frente Farabundo Martí para la Liberación Nacional, FMLN), the guerrilla army that formed in October 1980 to fight the Salvadoran government.

Santiago was not a fighter, although he did sometimes carry a gun and he lived through numerous battles and aerial bombardments. Rather, he was a radio announcer, the main voice for the FMLN's clandestine radio station, Radio Venceremos (Radio We Will Win). For eleven years, he and his fellow team members broadcast news and variety shows from a mobile radio transmitter in Morazán, oftentimes on the run or under bombardment. The Salvadoran Army and its U.S. ally called Radio Venceremos a propaganda tool and a weapon of war, and, indeed, sometimes it was. But it also provided the primary alternative to the mainstream media sources, which provided an unvarying progovernment viewpoint. Radio Venceremos became one of the army's highest priority targets.

What you are about to read is Santiago's journal of his first four years of 
the war, beginning with his arrival in Morazán in December 1980 and ending in late 1984, when the FMLN guerrillas reached a military stalemate with the army. After reading his account of the harrowing first four years under fire, it is remarkable to think that the war lasted yet another seven years.

Santiago's story is very personal and provides the insights of one man working and surviving in an intense war zone. In that regard, the journal reveals deeply individual emotions of love and loss, happiness and tragedy. But Santiago's memoir also tells a broader story, of the nationwide rebellion and its international context, particularly the intensifying cold war and the heavy involvement of the United States under Pres. Ronald Reagan.

El Salvador's civil war killed as many as 75,00o people, wounded another 350,000 or more, sent at least one million into exile, and cost billions of dollars, all in a tiny nation about the size of Massachusetts with a population of around 5 million. Such heavy costs do not occur without intense disagreement over why the fight happened. Subject to acrimonious debate were such issues as the cause of the war, the goals of the rebels, the quality and character of the Salvadoran government and army, and the wisdom of U.S. policy.

In a 1984 address to the nation, Pres. Ronald Reagan told his listeners that "El Salvador [has] become the stage for a bold attempt by the Soviet Union, Cuba and Nicaragua to install communism by force throughout the hemisphere." $\mathrm{He}$ said the United States would do everything in its power to stop the spread of communism in Central America and therein defend the United States. As is evident from his speech, Reagan believed, or at least wanted his listeners to believe, that El Salvador was the new front line in the cold war.

Suddenly, the small and previously insignificant country of El Salvador assumed center stage in the international drama of cold war politics. Hawkish anticommunists like Reagan found themselves throwing their lot in with El Salvador's elites, army, and government, with their abysmal track record on human rights. Reagan's domestic opponents in the Democratic Party balked at his administration's unbridled support of the Salvadoran government, but ultimately they did not want to appear soft on communism before their constituents. And so the aid flowed unabated to El Salvador to the tune of more than one million dollars per day for eleven years.

The Salvadoran elites and their allies in the army and government also portrayed the fight in El Salvador as part of the cold war. They commonly appealed to anticommunism and nationalism and insisted that El Salvador was being threatened by the Soviet Union, Cuba, China, or Nicaragua, or all four at once. But for all their posturing toward international affairs, the elites, the army, and the government all knew that the war was much more personal and local. They understood that they were fighting to defend what they possessed against those in their country who had nothing. The difference is that they believed they had a right to 
their lot and that the best thing for the country was for them to be allowed to continue doing what they had been doing. In that regard they defended themselves in the name of capitalism, Christianity, liberty, and even democracy. Meanwhile, they labeled their opponents as communists, terrorists, and subversives.

For their part, the rebels defined their insurrection as an attempt to end once and for all El Salvador's system of exploitation and exclusivity. They argued that a tiny clique of elites had been running El Salvador like a personal fiefdom for decades, if not centuries. As part of that system of rule, the elites had formed a pact with the army, allowing officers to govern the country as long as they left the elites alone and crushed all opposition. The rebels pointed to repeated attempts to change the system through nonviolent means, only to see every effort violently overcome.

Most of the rebels were poor peasants from rural areas who enlisted in the guerrillas through a radicalized Christianity and an embrace of a theology of social justice. Few cared about communism. A small minority of the guerrillas, the leaders mostly, were educated urbanites, and some of them were committed Marxist-Leninists while others were social democrats. Regardless of their differences, the guerrillas stood united in the belief that their fight was just and that their use of violence constituted a form of self-defense. Against accusations that they were stooges for international communists, the guerrillas pointed to the strong diplomatic and financial support from European countries, nonaligned nations of the developing world, and even U.S. citizens who donated millions of dollars to the FMLN's cause. The rebels claimed that they acquired many of their weapons from the black market, or, as Santiago will show in his memoir, by capturing them from the Salvadoran Army.

As should be evident, any interpretation of El Salvador's civil war is going to be partisan or biased and reflect the interpreter's perspective. This includes the memoir you are about to read, the Introduction I am writing for you, and Ronald Reagan's address to the nation in 1984. As the saying goes, one person's freedom fighter is another person's terrorist. Naturally, Santiago's is a partisan account. After all, he was a guerrilla and he believed the insurrection was just and necessary, albeit tragic and unfortunate. As you read his account, you will see that he celebrates guerrilla victories, bemoans the loss of his compañeros (comrades), and celebrates the army's retreat. At first blush his memoir might seem to portray an unmitigated guerrilla success, notwithstanding the many guerrillas who died in the process. But the fact of the matter is that, during the period covered by the book (1980-1984), the guerrillas scored some of their most impressive military victories. During those years, they pushed the state to the brink of collapse and gained control over 25 percent of Salvadoran territory. It is commonly accepted that had it not been for massive aid from the United States, the guerrillas would have won. 
But simply because an interpretation is partisan does not make it wrong. It is up to the reader to weigh the evidence and determine the viability of any given argument based on the use of sound methodological principles. For the reader who might be unfamiliar with the civil war in El Salvador, let us get one fact established: the overwhelming majority of human rights abuses that occurred during El Salvador's civil war were committed by the Salvadoran Army and its paramilitary affiliates. The United Nations Truth Commission found that between 85 percent and 90 percent of the human rights violations were perpetrated by the army and its paramilitaries, somewhere between 5 percent and 10 percent were committed by the guerrillas, and 5 percent cannot be assigned responsibility. ${ }^{2}$

It is a common tactic of the Right in El Salvador and its supporters in the United States to say things like "bad things happened during the war, and both sides made mistakes and committed atrocities, so let's move on." A major consequence of this perspective was the blanket amnesty pushed through by the conservative ARENA (Partido Alianza Republicana Nacionalista, National Republican Alliance Party) government after the war. But only one side-the army - used widespread terror in the form of torture and indiscriminate massacres of unarmed civilians to advance its cause. The guerrillas' violations revolved mostly around kidnapping elites for ransom and assassinating local political officials in guerrilla-held territory who refused to surrender office. The guerrillas were widely recognized as treating their prisoners according to international rules of war. In fact, they hoped their prisoners would join their ranks, and treating them fairly was part of that objective. Therefore, it is methodologically unsound to speak of the guerrillas' human rights violations as being anything comparable to the army's. Santiago's memoir will reflect these facts.

The remaining pages of this Introduction will set the stage for Santiago's story of those four years in Morazán. It will provide an overview of El Salvador's civil war, with a focus on northern Morazán and the emergence of the ERP.

\section{Morazán and the Theater of War}

In a country marked by poverty and inequality, the department of Morazán has been and continues to be one of the poorest and most remote in El Salvador. Located in the far northeastern corner of the country, it has no main highways passing through it, and its thin, rocky soils are not good for growing crops (see Map 1). Its residents are mostly poor peasants who try to survive on small plots of land, and the few wealthy families that live in Morazán made their money through commerce or by controlling the limited commercial agriculturemostly coffee grown at higher elevations. ${ }^{3}$

Morazán is shaped like a rectangle measuring roughly twenty miles on one 
side and fifty miles on the other. It slopes upward from south to north starting at around five hundred feet above sea level at its southern end, the border with San Miguel department, to around six thousand feet above sea level at its northern end, the border with Honduras. At the outbreak of the civil war Morazán had approximately 175,000 inhabitants, a number that today has grown modestly to 250,000. The department has twenty-six municipalities, the largest of which is its capital, San Francisco Gotera, with close to 20,00o residents. Most of the remaining twenty-five municipalities have fewer than 10,00o inhabitants, and since they tend to live in homesteads scattered throughout the countryside, those towns rarely measure more than four square blocks in size.

The guerrilla stronghold in Morazán during the war was the northern third of the department, a roughly ten-by-twenty-mile rectangular area north of the Torola River (see Map 2). This region contains only eight of the department's municipalities, and it had approximately 30,000 people at the outbreak of the war. Half of those people fled the region by 1982 to avoid the fighting. ${ }^{4}$

Northern Morazán is a beautiful region. Its various hilltops and ridgelines afford panoramic vistas. It has a couple of small but attractive rivers, the Sapo and the Torola. The air is clean and fresh, and pine forests grow at the upper elevations. With good reason entrepreneurial residents today are trying to promote the region as a tourist destination. For outsiders who did not live there in the 1980s, it is hard to image how such a tranquil place could have been the site of such a long and horrific war.

Another surprising aspect of northern Morazán is its small size and its seeming inadequacy for a guerrilla insurgency. The terrain is not particularly rugged or difficult to traverse. It offers no jungle, a few modest-sized mountains, and its pine forests and brush offer some cover, but hardly enough, it would seem, to hide a guerrilla army. In short, northern Morazán would not seem a good location to launch a guerrilla insurgency, especially when the enemy's air force had total command of the skies.

Since most readers of this Introduction will never have been to northern Morazán, a brief visualizing exercise might help you to understand what it looks like. Imagine a shallow bowl about the size of a laptop computer. Now imagine a post standing upright in the middle of it about the size of a AA battery, such that the top of post is more or less level with the rim of the bowl. That post represents Pericón Hill, which is located more or less in the middle of northern Morazán. Imagine the floor of the bowl to be approximately 2,500 feet above sea level and the rim to be around 6,00o feet above sea level. Now imagine yourself standing on top of that post (Pericón Hill) looking north. Straight ahead of you and to your right is the mountain range (the rim of the bowl) that marks the border between El Salvador and Honduras, only ten miles away. The rim of the bowl behind you to the south represents two other small mountain ranges, the Ocotepeque 
Mountains over your right shoulder and the Cacahuatique Range over your left shoulder. They lie slightly to the south of the Torola River, so officially they are outside the region considered to be northern Morazán, but they represent the southern end of guerrilla territory. The Torola River cuts across the floor of the bowl about mid-distance between you and those mountains to the south.

Continue to imagine yourself standing on top of that post (Pericón Hill) looking north. Now imagine another post to your left, also about the size of a AA battery. That is Gigante Hill, which sits approximately two miles almost due west from you. Now imagine another post just to the north of Gigante, so to your left and slightly in front. That is Perquín Hill. Imagine a small town tucked into the side of that post about one-quarter of the way down from the top; that is the town of Perquín, the so-called guerrilla capital in Morazán during the war.

There are no major mountains on the other side of Gigante Hill to your left, so you need to image the rim of the bowl giving way to a series of undulating hillsides and plains extending westward as far as the eye can see. In that direction is Cabañas department, and on the other side of that is another guerrilla stronghold during the war, northern Chalatenango department, approximately forty miles away. Pericón Hill affords a nearly 360-degree view of the bowl that is northern Morazán. And on a clear day if you are looking westward, you can see all the way to the capital city of San Salvador, approximately sixty miles away. The city itself is not visible because it is nestled down into its own bowl, but you can make out the six thousand-foot volcano that stands behind it.

The bowl of northern Morazán was a main theater of war for eleven years, between 1981 and 1992. When you take into account that the Salvadoran Air Force had helicopters and fighter-bombers that could arrive at the region from their bases within minutes, and the Salvadoran Army could place as many as ten thousand heavily armed soldiers in the region, it defies logic that a guerrilla army could survive there for eleven years. So how did the guerrillas do it?

As with any guerrilla army, mobility was one of the ERP's most important traits. The guerrillas' mobility turned the small size of northern Morazán into an asset rather than a liability. The guerrillas preferred to avoid direct confrontations with the army except by their own choosing, because the Salvadoran military held a decided advantage in firepower and supplies. It was smarter for the guerrillas to pick their fights when they could be assured of an element of surprise or when they could use the natural surroundings to their advantage. Otherwise, the guerrillas tried to stay one step ahead of the army, even if that meant fleeing Morazán entirely.

Even though the guerrillas possessed no vehicles and had to travel everywhere by foot, they moved quickly. They possessed intimate knowledge of the terrain, and northern Morazán was not large, so they could leave it in one or two days of 
marching. On the six or so occasions during the war when they fled the region entirely, the guerrillas headed west, south, or southeast to safe havens to wait out the army's occupation. If the guerrillas' ability to escape seems unfathomable, realize that a fit backpacker carrying a forty-pound load can walk between two and three miles per hour for eight to ten hours. The guerrillas were well trained, and so most of them could leave the region in one steady nighttime march.

Another key weapon in the guerrillas' arsenal was intelligence. Avoiding a surprise attack was possible by acquiring information about the army's plans. As long as they knew when the army was coming and from what direction, the guerrillas could plot an attack strategy or map an escape route. They had sympathizers throughout the country, even within the army itself, and so the army rarely caught them off guard with major attacks. When the army planned major ground offensives in northern Morazán, it had to move massive amounts of troops and supplies, which gave the guerrillas days, even weeks, of notification. Furthermore, the guerrillas were usually able to monitor army communications through captured radios and by cracking military codes. Former soldiers who sided with the guerrillas provided a constant update of army codes and plans. The guerrillas also had the advantage of a few army officers joining their ranks, such as Captain Mena Sandoval, who brought a wealth of information on military strategy and tactics. ${ }^{5}$

In addition to being mobile and well informed, the guerrillas were proficient fighters. The quality of their weaponry may have paled in comparison to the army's, but the guerrillas were well trained in using what they had. Whenever the army left itself exposed, the guerrillas delivered stinging blows that forced hasty retreats. The guerrillas were nothing if not flexible and fast acting, and so, even on the run, they could turn and make the army pay for pursuing them.

An astute reader might ask why the army simply did not stay in northern Morazán when it managed to chase the guerrillas out of the region, or why it did not find out where the guerrillas were fleeing to and pursue them. After all, the army could invade the region with upwards of ten thousand troops backed up by helicopters and fighter-bombers. They also had the advantage of the U.S.-backed Honduran Army blocking the northern border to prevent the guerrillas from fleeing in that direction or using Honduras as a staging ground. By comparison, the guerrillas in northern Morazán never numbered more than five thousand armed combatants, and more typically their numbers were closer to fifteen hundred. So why couldn't the army simply hold onto the terrain once it invaded?

The mobility of the guerrillas meant that they could attack almost any selected army stronghold throughout northern Morazán at their choosing. Normally, being on the defensive in a military engagement is an advantage, but having to defend multiple physical locations throughout an entire region forced the army to spread its resources thinly. In contrast, the guerrillas could pick and choose 
their target and concentrate their firepower on that one location. Thus, they could usually overwhelm any single army outpost. Sometimes the guerrillas attacked an outpost simply to draw in their preferred target: reinforcements coming from another town. Slowly but surely the guerrillas bled the army out of northern Morazán, one outpost at time, with the last post, Perquín, falling once and for all in early 1983 . To have defended every town and hamlet in northern Morazán, and to have held onto them in perpetuity, the army would have had to post many thousands of troops. Simply put, it lacked the manpower. After the army had been pushed out of the region, the guerrillas employed the same strategy to rebuff each of its attempts to reestablish control: concentrate firepower on one outpost after another until the army once again gave up and left.

The other factor favoring the guerrillas in northern Morazán is that they constituted only a portion of the FMLN's total army, and their front was only one of three of four throughout the country (see Map 1). The FMLN comprised five distinct guerrilla factions, each of which tended to predominate in a particular geographic region. The two largest and most combative factions were the Popular Liberation Forces (Fuerzas Populares de Liberación, FPL) in Chalatenango and the ERP in Morazán. The other three factions, the Armed Forces of Liberation (Fuerzas Armadas de Liberación, FAL), the National Resistance (Resistencia Nacional, RN), and the Revolutionary Party of Central American Workers (Partido Revolucionario de los Trabajadores Centroamericanos, PRTC), were spread out between the Guazapa volcano, Usulután department, and San Vicente department. Thus, the army's problem of defending multiple positions at one time applied not only to individual geographic regions, like northern Morazán, but also to the entire country. If the army dedicated a large portion of its combatready troops to one region, then it exposed itself on two or three other fronts, where the guerrillas could deliver devastating attacks. Even though the army had anywhere from five to ten times more active-duty soldiers than the guerrillas (between 50,000 and 100,000 to the guerrillas' 10,000 at most), as well as tens of thousands more people serving as auxiliaries in the paramilitaries and the army reserves, most of the government's troops were basically serving as guards. They protected municipalities or infrastructure from the guerrillas. Ultimately, the number of combat-ready troops in the army was not that much higher than the guerrillas had access to. Most of the actual fighting by the army was performed by a few select Special Forces battalions, such as the notorious Belloso and Atlacatl.

\section{Liberation Theology and the Peasantry of Morazán}

Another major reason the guerrillas were able to beat the odds and survive in the small region of northern Morazán was their well-established social network. Most of the guerrillas fighting in northern Morazán were poor peasants from 
the region. They might best be described as peasants in arms defending themselves against a government they deemed illegitimate.

The process by which some peasants in Morazán developed this militant consciousness and decided to take up arms against the government leads us to ask a more basic question: Why do peasants rebel? Certainly, poverty and exploitation are raw materials for inciting an armed insurrection. But poverty and exploitation by themselves are not adequate explanations. Poverty and oppression are ubiquitous, but insurrections are rare events. In fact, unabated, grinding poverty usually hinders rebellion, because the people living in those conditions have been downtrodden for so long that it is inconceivable for them to risk what little they have. Instead, rebellions usually occur when some sort of trigger breaks the cycle of dependence. ${ }^{6}$

As a historically isolated and impoverished region, Morazán was a good candidate for an armed insurrection. But what stands out about Morazán is that its history does not provide evidence of any triggers. No major changes in the economic or social structure occurred in the region in the 1960s or 1970 . Neither was there a sudden interest in the region from capitalist farmers or industrialists who might have expropriated peasant lands for commercial purposes. And there had been no economic boom-and-bust cycle in the region that might have given peasants hope, only to dash them in an economic collapse. The region was affected by the inflationary pressures of rising oil prices in the early 1970s, as well as the political turmoil of fraudulent presidential elections in 1972 and 1977. But those events occurred throughout El Salvador, and, furthermore, such depressing economic and political conditions had been typical in Morazán for decades. So why, then, would Morazán emerge as such a hotbed of insurrection in the 1970s and 1980s?

The answer to this question is found in the history of a radicalizing Christianity and the growth of a new interpretive consciousness among Morazán's peasants. Starting in the late 1960 s and early 1970s, a new consciousness, primarily Christian in origin, began to take hold among Morazán's peasants, and some of them began to translate that consciousness into militant action. This new consciousness had its roots in the emergent liberation theology of the Catholic Church, represented by the Second Vatican Council (1962-1965) and the Latin American Bishops' Conference in Medellín, Colombia, in 1968. Those two events marked the emergence of a modernizing trend within the Catholic Church in which Catholic hierarchs called on their followers to take up the "preferential option for the poor," or to make the plight of the poor a focal point of their faith. The new trend divided Catholics throughout the world between conservatives and reformers.

In El Salvador, the liberationist reformers were found in such places as rural Christian Base Communities (Comunidades Eclesiásticas de Base, CEB), the new 
Christian Democratic Party, the Central American University (Universidad Centroamericana, UCA), the private Catholic secondary school-the Externado de San José-the San José de la Montaña seminary, and the San Salvador bishopric.

Morazán was a stronghold of the conservative wing of the church, but even there liberation theology made inroads. Morazán falls under the bishopric of San Miguel, which was led by two conservative bishops, Lorenzo Graziano (19681969) and Eduardo Álvarez (1969-1997). Northern Morazán was contained within a single diocese located in Jocoatique that had a single priest, Andrés Argueta, also a conservative and an ally of the bishops in San Miguel. One of the reforms of Vatican II and Medellín was to allow nonordained lay workers to perform some sacraments in hopes of reducing the problems associated with the lack of priests throughout the world. Nowhere was this problem more acute than in northern Morazán, with its one priest per thirty thousand parishioners.

To train these new catechists, training centers were opened throughout the country. One was founded in the Castaño neighborhood of San Miguel city and was called the Centro Reino de la Paz (Prince of Peace Center); but it was more commonly known as El Castaño. Two other centers opened nearby, one also in San Miguel city and the other in the town of Jiquilisco in Usulután department. In 1968 Bishop Graziano ordered priests throughout his bishopric to find promising candidates and send them for catechism training in these centers. Obligingly, Father Argueta in Jocoatique began sending recruits to El Castaño from northern Morazán.

Unbeknownst to Argueta, and presumably to Bishops Graziano and Álvarez as well, and certainly unbeknownst to the catechist recruits, the training centers were heavily influenced by adherents of the new liberationist theology. The teachers in the centers defined their mission in much broader terms than simply educating peasants in catechism. Instead, they believed it was their responsibility to empower their pupils by giving them the means to employ Catholic teachings to interpret their daily lives for themselves. One of the main scholars to conduct work on this critical period of Morazán's history, the North American anthropologist Leigh Binford, gathered the following testimony from one of the pupils at El Castaño, expressing her surprise at the curriculum and the nontraditional conduct of the priest-teachers:

When I arrived at the center [El Castaño], I was a bit concerned and I asked myself, "What are we going to do here?" At that time the schedule for each day had been written up, and I was looking at it. Well, at such an hour [one class] and such an hour another class. They had themes on community development, health education, agriculture and free themes. I asked myself, "To combine these things as a Christian, how's it going to happen?" I thought they were going to teach us things about the Bible and to pray.... 
The other thing that bothered me a bit is that I was accustomed to seeing priests in dressed in pants and cassocks. But as I watched them wearing teeshirts and playing soccer with the masses ... well when one has a preconception, all that is a bit strange.

The priest-teachers at El Castaño faced a variety of problems from their pupils, including passivity, an inability to think critically and independently, and discomfort with speaking in front of groups. The teachers subsequently designed exercises to promote independent thinking and extemporaneous speaking. In a relatively short time, the teachers' work began to produce results. The pupils began to think for themselves, and they soon acquired a great proclivity for public speaking. In fact, one of the teachers joked that in time he began to dread the sessions dedicated to public speaking because his pupils spoke at great length without concern for time. ${ }^{8}$ Another priest from northern Morazán noted that the peasants were not stupid or incapable; quite the contrary. They proved tremendously adept and demonstrated a strong desire to learn new skills and apply them to improve themselves and their communities. ${ }^{9}$

Some of the pupils who demonstrated a high capacity were invited to attend additional courses in other training centers, even abroad in Guatemala and elsewhere. In time, dozens of recruits from northern Morazán passed through El Castaño and the other training centers. Not all of them welcomed or embraced the liberationist curriculum, but most did, and those are the ones who returned to their communities anxious to apply the lessons they had learned. They organized meetings and invited community members to speak out about their problems and to propose solutions. They began forming cooperatives to improve people's lives by sharing both the risks and rewards of agricultural production.

As Binford points out, it would be wholly inaccurate to describe the centers as fomenters of rebellion or militant insurrection. The centers' educators wanted to teach self-help, autonomous thinking, and community development. But in the midst of El Salvador's traditional social structures, such seemingly innocuous ideas possessed radical potential. If peasants and other poor people demonstrated independent thinking, then by definition they were becoming less pliable, and less willing to accept the standard explanations that politicians, soldiers, elites, and conservative priests had been giving them for generations. If they sought their own solutions to daily problems, then by definition they were breaking away from the cycle of dependence and passivity that allowed traditional authorities to rule. And when the defenders of traditional power structures felt their control slipping, they responded with unmitigated violence.

A decisive event that contributed to the evolution of consciousness among the peasants of northern Morazán was the appointment of a new priest to the region in 1973 . That priest was a young seminarian named Miguel Ventura, who 
had studied in the San José de la Montaña seminary in San Salvador and was an adherent of the new liberationist theology. On completing his training, Ventura was assigned to the San Miguel bishopric, much to the chagrin of Bishop Álvarez, who knew the young Ventura and his views. Álvarez delayed posting Ventura for as long as he could, but eventually he assigned him to the safest alternative, a new but remote diocese consisting of three municipalities in northern Morazán. At least there he would be under the watchful eye of the conservative Father Argueta.

\section{The ERP and Rural Militancy in Morazán}

It did not take long for Ventura and the Catholic lay workers who had received training at El Castaño to emerge as a potent force for social change. In response to the emergence of this new consciousness, Álvarez transferred the young Father Ventura the following year to the diocese of Osicala, still in Morazán, but farther south and closer to San Miguel. However, before he was transferred, Father Ventura helped consolidate northern Morazán as a seedbed for militant peasants by arranging a meeting between some of the catechist leaders and Rafael Arce Zablah, a young leader of the recently formed ERP guerrilla faction. Ventura recalls meeting Arce Zablah in Torola in late 1973 or early 1974, at which time Arce Zablah shared with Ventura his plans for overthrowing the Salvadoran government. ${ }^{10}$

The first meeting between Arce Zablah and the peasants occurred in a convent in Planes de Renderos on the outskirts of San Salvador in April 1974. Apparently, two other meetings occurred in Morazán before Arce Zablah was killed in a failed assault on a national guard post in El Carmen, La Unión, in 1975. In those meetings, Arce Zablah informed the peasant leaders of his belief that Morazán was the appropriate staging ground for the looming war against the Salvadoran state. Arce Zablah originated from Usulután, and he apparently believed eastern El Salvador to be ripe with revolutionary potential. He proposed that the peasants form clandestine military committees as the cornerstones for organization and preparation. The peasants responded by organizing military committees in or around the towns of Jocoatique, Meanguera, and Torola. ${ }^{11}$ Those meetings and the military committees that grew out of them planted a seed of connectivity between the radicalizing Christian peasants of northern Morazán and the nascent urban guerrillas from San Salvador. In time that link would grow into a broad rural insurrection. ${ }^{12}$

Romantic revolutionaries consider the link between peasant farmers and urban workers to be natural. One example is the hammer and sickle insignia of the Russian Communist Party, which signifies the supposed bond between urban workers (the hammer) and peasants (the sickle). The idea behind the 
insignia and those who subscribe to its meaning is that peasants and urban workers are members of the same economic underclass and are exploited equally by the existing economic system; therefore, they share a natural desire to work together to change it.

In reality, the gulf between peasants and urban workers can be wide. They can be like two nationalities living in the same country, with differing culture, family lines, linguistic dialects, and historical experiences. They also have differing stakes in the economic system. As food producers, peasants want food to sell at high prices, but as consumers, urban workers want food to be cheap. Historically, common fronts between peasants and urban workers have been the exception rather than the rule.

If the link between peasants and workers is difficult to establish, then a bond between peasants and affluent urban intellectuals is even more difficult. For the most part, the founding members of the ERP were urban intellectuals who emerged from the factionalism within the Left in the early 1970s. The ERP was founded in 1972 by a group of young, militant radicals who disagreed with the traditional line of El Salvador's Communist Party (founded in 1930) in regard to the timing of revolution. The Communist Party argued that El Salvador was not ready for revolution and therefore the proper strategy was to build electoral coalitions and organize labor unions. The young militants disagreed and argued that the revolution was pending.

The first faction to break from the party was led, ironically, by an elder Communist leader, Cayetano Carpio. In 1970 he founded the FPL. The second faction to form was the ERP. Almost all of the ERP's founders were young, universityeducated urbanites, including Joaquín Villalobos, Eduardo Sancho, Lil Milagro Ramírez, Ana Guadalupe, Rafael Arce Zablah, and Alejandro Rivas Mira. They were later joined by famed poet Roque Dalton, among others. Most of them came from working- or middle-class families and thus were hardly elites, but compared to the peasants of northern Morazán, they were affluent and well educated. They had arrived at their militant consciousness from a variety of avenues, including their classes at the university, their embrace of liberation theology, affiliation with the radical side of the Christian Democratic Party, and union organizing.

Why those young founders of the ERP did not join forces with the FPL is part of El Salvador's complex history of leftist politics. Suffice it to say that the Left in El Salvador exhibited an impressive ability to split ideological hairs and divide itself over minor issues. So, whereas for nearly forty years, El Salvador had had only one underground radical movement, the Communist Party, it now had three, two of which were dedicated to guerrilla warfare. By 1976 two more militant factions would emerge. It would then take another four years, until October 1980, for the five factions to unite in a common revolutionary front-the FMLN. 
Joining an underground militant organization in the early 1970 in El Salvador was a serious commitment. A militant had to surrender his or her past life, give up ties to friends and family, and dedicate herself or himself to the unending and challenging task of mobilizing an insurrection in secret. Fear of capture by state security agents was constant. Every militant knew that arrest meant horrific torture and probably death. All it took to be captured was a minor slip in security, betrayal by a comrade, or simply the bad luck of being stopped at a roadblock. Another great fear was that the security forces would learn the identities of a militant's friends or family and exact retribution from them. ${ }^{13}$

The ERP remained a small, secret organization throughout its initial years. Its members carried out a few kidnappings and bank robberies to raise funds. They also launched a few small military raids, like the one on the national guard post in 1975 that cost Arce Zablah his life. Throughout its early years, the ERP struggled with internal debates over ideology and strategy-the same types of disputes that had led to its formation in the first place. The lowest moment of these internal disputes occurred in May 1975, when some ERP leaders executed Roque Dalton on erroneous claims of treason and conspiring with the CIA. The debate about Dalton caused a group of members led by Eduardo Sancho to break away from the ERP and found the RN. A few months later, another faction broke away from the ERP under the leadership of Francisco Jovel and formed the PRTC. Beyond military assaults and fund-raising raids, the main goal of these nascent militant organizations was to recruit members and establish linkages throughout the country in preparation for war, hence the meeting between Arce Zablah and the peasants from Morazán in $1974 .{ }^{14}$

By the latter half of the 1970s, as conditions worsened in the country, recruitment for the five underground organizations grew. Each of them formed ties with a popular front that kept public pressure on the government through nonviolent marches, demonstrations, and protests, frequently held in San Salvador. The ERP's mass front was the February 28 Popular League (Liga Popular 28 de Febrero-LP-28), which was formed in early 1978. Often it was the nonmilitant members of these mass organizations who suffered the worst acts of state repression by exposing themselves publicly to beatings, shootings, or arrest.

Conditions in northern Morazán deteriorated in the late 1970s as well. State security forces and paramilitary units monitored, harassed, and attacked suspected peasant leaders and the organizations they had built. A decisive moment in the evolution of tensions occurred in November 1977, when security agents killed Juan Ramón Sánchez. He was a peasant catechist who had been trained in El Castaño and who had affiliated with the ERP. During a surprise roadblock near Osicala, Sánchez engaged in a shootout with army commandos that left him and three soldiers dead. In response, security agents launched a roundup of anyone they suspected of involvement in progressive Catholicism or community 
organizing. As part of that sweep they arrested and tortured Father Ventura until public pressure forced them to release him two weeks later. Ventura went into exile and did not return to Morazán for five years. Many other catechists, peasant leaders, and their family members were arrested, tortured, and/or killed. ${ }^{15}$

In response to increasing repression from state security forces, more peasants throughout northern Morazán embraced an armed strategy and began to affiliate with the militant committees of the ERP. According to Father Ventura, a local Christian agricultural youth organization, the Juventud Cristiana Agrícola, had ties to the ERP and served as a source of recruitment and organization. ${ }^{16}$ On account of the increasing intensity of conflict and the growing levels of state repression after 1977, it is not uncommon to hear former activists speak of the war as starting in 1977 rather than the official start date of January $1981 .{ }^{17}$

The army launched its first scorched-earth offensive throughout northern Morazán on October 10, 1980. The peasant militants organized as part of their nascent ERP military committees slowed the army's advance, but could do little more. On October 13 the army committed its first of many massacres in the region, killing nearly one dozen unarmed civilians at La Guacamaya, in the municipality of Villa El Rosario. During that offensive nearly one thousand noncombatants fled across the Honduran border to Colomancagua, which would become an official United Nations-supplied refugee camp the following year. ${ }^{18}$

Between 1977 and 1981 each of the various guerrilla organizations continued to nurture its base of support in both urban and rural areas. The rural strongholds for the two largest guerrilla factions, the FPL and the ERP, were Chalatenango and Morazán, respectively. The other, smaller, guerrilla factions established footholds elsewhere, including San Vicente and Usulután departments, and around the Guazapa volcano north of San Salvador.

But until the failure of the first offensive in January 1981, the urban areas remained at the forefront of the guerrillas' strategic plans. It was not their intention to entrench themselves in rural areas and fight a decade-long civil war with a peasant army. Especially after the success of the Sandinistas in Nicaragua in July 1979, the Salvadoran guerrillas believed that they could dislodge the Salvadoran government after a quick, concerted push in which urban areas would play a decisive role. The product of this belief was the first Final Offensive, launched by the various guerrilla factions after they banded together into the FMLN in October 1980. Indeed, the launching of the Final Offensive in January 1981 marks the official beginning of the civil war in El Salvador. The failure of that offensive made it impossible for the guerrillas to maintain an operational presence in the cities. They retreated to safer havens in rural areas and prepared for a longer conflict. ${ }^{19}$ It was at this moment that the civil war in El Salvador assumed the character of a protracted rural insurrection. 


\section{The War in Morazán}

As part of its new strategy after the offensive in 1981, the ERP directed its military energies toward northern Morazán. Following the strategy discussed earlier, the ERP first cleared the countryside of paramilitary agents and government security forces and then systematically attacked one military outpost after another. The ERP's goal was to clear the military out of the region and create a liberated zone that would serve as its rear guard. From that stronghold, it would expand its control outward, join up with the other guerrilla fronts, and eventually march into San Salvador victorious. At least this was the ERP's strategy, which tended to emphasize a militarized approach of engaging the army in combat and seizing control of territory.

The FPL adopted a slightly different approach by emphasizing social and community organization and relying on militias rather than a standing army as the ERP did. But in the end, both organizations employed a similar strategy of maintaining combat-ready guerrillas to engage the army and working with noncombatant communities to provide social services. ${ }^{20}$

It took the ERP nearly two years to clear the army out of northern Morazán. In the meantime, the army implemented a scorched-earth policy in which regular troops and its new Rapid Action battalions, like the Atlacatl Battalion, turned northern Morazán into a free-fire zone, or so-called Red Zone, in which anyone found there was assumed to be a guerrilla or guerrilla sympathizer. The army's goal in these sweeps was to find and kill guerrilla combatants, but when the army failed to do that, which was typical, it tried to destroy the region's ability to sustain the insurgents. The strategy devolved into widespread crop and livestock destruction and massive human rights violations. The most well known army massacre, but just one of many examples, occurred in El Mozote in December 1981. ${ }^{21}$ The vast majority of the one thousand victims at El Mozote were evangelical Christians and disinclined toward the guerrillas.

The army's departure from Perquín on the twenty-third of February 1983 marked the moment at which the ERP established control over northern Morazán once and for all. This two-year period between 1981 and 1983 is sometimes identified as the extended First Offensive. Even though the FMLN failed to take control of San Salvador in January 1981, it did manage over the next two years to push the army out of nearly 25 percent of El Salvador's territory.

During this period of guerrilla ascendance, the ERP established a large and proficient combat force. Under the guidance of Captain Mena Sandoval and other former army officers, the ERP assembled six standing combat battalions consisting of as many as five hundred soldiers each. They were named after the fallen ERP leader, Arce Zablah, and were referred to by the acronym BRAZ_Brigada Rafael Arce Zablah (the Rafael Arce Zablah Brigade). The goal of these units was 
to engage the Salvadoran army in direct military battles, and during the first two or three years of the war, BRAZ units carried out some legendary missions. One of them was the assault on the army's communications center atop a mountain in the Cacahuatique range. The center's defense plan had been designed by U.S. military planners who considered the site impenetrable. But BRAZ units exploited a weakness and seized control of the center in a daring raid in May 1983.

On repeated occasions, ERP commandoes attacked the main military barracks of the Third Brigade in San Miguel, well outside their zone of control in northern Morazán. Such striking ability kept the army on the defensive and relieved pressure on the guerrillas' home base in the north. For example, after the second major assault on the barracks in May 1984, the military pulled back many of its troops from the Morazán region. Another memorable mission was the joint FPL/ ERP raid on the Salvadoran Air Force at the Ilopango airfield in January 1982. Commando units penetrated the airbase's perimeter and destroyed much of the Salvadoran Air Force while planes and helicopters sat on the tarmac.

These and other victories stirred optimism among the guerrillas and their supporters, notwithstanding the hardships and losses that the brutal war exacted. ERP combatants in particular considered themselves the premier combat units among the guerrillas, and they took pride in having created a fighting force that could confront the enemy and win. As Joaquín Villalobos, the ERP commander, put it in late 1982, "We have achieved a strategic accumulation of victories which will be expressed in a final culminating moment." ${ }^{22}$

Despite their victories, FMLN leaders realized that maintaining a large standing combat force was a costly strategy doomed to fail without a fast victory. Its large combat units were less mobile and more easily detected by the enemy, especially from the skies. Also, standing combat units required large amounts of supplies, which were difficult to acquire.

Fearing a guerrilla victory, the Reagan administration redoubled its aid efforts to the Salvadoran government in late 1983 and early 1984, which included restocking the air force with helicopters and fighter-bombers. Without victory readily in sight, and confronted by a freshly resupplied enemy, the FMLN leadership changed its strategy. Instead of retaining large standing combat units like the ERP's BRAZ in Morazán, it downsized. The new strategy relied on smaller, more mobile units that would now fight a war of attrition rather than a war of engagement. The smaller units employed hit-and-run tactics that would drain the army of its ability and will to fight rather than defeating it outright in combat. New targets included infrastructure or anything that would cost the Salvadoran government money to replace. The idea was that over time the Salvadoran state would simply collapse under the economic drain. ${ }^{23}$

The dismantling of the BRAZ in early 1984 was a difficult and demoralizing period in the ERP's history in Morazán. The decision to downsize was not 
universally supported, and some combatants left the ranks. Another component of the new strategy that met with opposition in the region was mandatory training for all civilians. The idea behind the strategy was to diffuse the striking power of the guerrillas throughout the population and to have a reserve of trained recruits available if needed. However, some families interpreted the mandatory training as a form of conscription, and many fled the region to avoid it. One of the guerrilla leaders who oversaw the training sessions, Marisol Galindo, recalled popular opposition to the new strategy during a 2008 interview. ${ }^{24}$

After reaching the nadir caused by its new strategy, the ERP recovered quickly. The smaller combat units were still potent, especially whenever the army entered northern Morazán. And as always, the army remained constantly concerned about guerrillas attacking locations outside their stronghold. A stalemate emerged between the army and the guerrillas that resulted in extended periods of relative calm in northern Morazán. During those lulls the guerrillas focused on community development and provided services to people throughout the region. Over the next few years a vigorous civil society emerged in northern Morazán in which a sort of parallel government formed and provided everything from education and health care to a judicial system. ${ }^{25}$ The guerrillas' new strategy and its stalemate with the army remained more or less in place until the FMLN launched its second Final Offensive in November 1989.

\section{Santiago and Radio Venceremos}

A major limitation for opposition organizations in El Salvador in the 1970s was their lack of access to the mass media. All the major media sources were controlled by interests loyal to the government and elites. Needless to say, those sources vilified guerrillas as terrorists and criminals while portraying the army and the government as righteous defenders of the population. The guerrillas had few ways to rebut these claims. They spray-painted slogans on walls and handed out flyers surreptitiously at marches and rallies. They also launched their first radio station in the late 1970 s from the grounds of the National University. But it had limited range and was shut down as the civil conflict in the urban areas intensified. ${ }^{26}$ Such methods hardly countered the relentless barrage from progovernment media sources.

As preparations for the first Final Offensive were under way, some guerrilla commanders became acutely aware of the problems caused by the lack of access to mass media. Particularly worrisome to those commanders was the fact that the offensive was designed around the emergence of a mass insurrectional wave that the guerrillas would ride to victory. Such a plan would fail if the population did not know about the offensive. According to Santiago, it was the ERP commanders, and particularly Joaquín Villalobos, who understood this problem and 
looked for solutions, such as the first radio attempts in San Salvador in 1979 and 1980. As the Final Offensive approached, a Venezuelan known as "Maravilla," who was working in Nicaragua, offered his services to the ERP commanders to help resurrect their clandestine radio. Maravilla told them that he had an ideal candidate for the job, another Venezuelan who was working in radio in Nicaragua at that time-Carlos Henríquez Consalvi. The ERP commanders accepted his offer, and the next thing Santiago knew, he was on his way to El Salvador. What he didn't know is that he would spend the next eleven years of his life there in a war zone. ${ }^{27}$

It took a remarkable series of circumstances for Santiago to be available to join the fight in El Salvador in late 1980. He was born in 1945 in Mérida in the mountainous interior of Venezuela. His father, Rigoberto Henríquez Vera, was politically active and opposed Marcos Pérez Jiménez (1914-2001), who ruled Venezuela between 1952 and 1958. Rigoberto was jailed and exiled repeatedly for his political activities, and so Santiago spent a portion of his youth in exile, particularly in Mexico. He says he grew up in an activist environment, hearing stories about politics from his father and his father's friends. He says it was almost unavoidable that he was going to be politically conscious as he grew older, given the environment in which he was reared and the broader context of Latin American politics in those days, when it seemed as if the whole continent was on the verge of massive social change.

Santiago's family returned to Venezuela after the fall of Pérez Jiménez, and he went on to enroll in journalism at the Universidad Central de Venezuela. He says he chose journalism as a field of study because it allowed him to investigate pressing issues and to be part of the unfolding political drama. It was while he was studying in Venezuela that a major earthquake struck Nicaragua in $1972 . \mathrm{He}$ and a group of politically conscious students decided to go there in December of that year to help out. While there, he became enamored of a young Nicaraguan woman who was politically active and linked to the clandestine Sandinista front. Santiago wanted to stay in Nicaragua amidst that devastating yet exciting time in the country's history, but he had to return to Venezuela to continue his studies. However, that brief visit to Nicaragua in 1972 put in motion a series of events that would cause Santiago to spend most of the rest of his life in Central America.

Santiago remained in contact with his new Nicaraguan girlfriend, and when the Venezuelan Army occupied his university in 1974, the two of them fled to Argentina, where he enrolled in journalism classes and she accepted an invitation to study music with none other than the famed Mercedes Sosa. Meanwhile, back in Venezuela, Santiago's father remained politically active, working as a journalist, a diplomat, and occasionally as a radio announcer.

Santiago ran into trouble with the military dictatorship in Argentina, so he and his girlfriend went to Paris to continue their studies. He enrolled in a history 
program and wanted to write his thesis on nineteenth-century Nicaragua, but his thesis advisor did not approve of his topic, so Santiago withdrew. He and his girlfriend went to Nicaragua briefly, and then he returned to Venezuela.

Finally, when the Somoza dictatorship fell in July 1979, he went to Nicaragua with the intention of staying indefinitely to aid the fledgling Sandinista Revolution. He began work as a photographer and journalist and had not been at it long before a Sandinista commander asked him to set up a bilingual Spanish/ Miskito radio station on the Coco River in northeastern Nicaragua. Santiago accepted the opportunity and began his new career as a radio announcer. It was while he was in northeastern Nicaragua that events in nearby El Salvador, like the assassination of Archbishop Romero in March 1980, drew his attention. It was also while in northeastern Nicaragua that Maravilla approached the ERP with the idea of setting up a clandestine radio station inside El Salvador with Santiago at the helm.

There was little precedent for what the ERP and its two Venezuelan counterparts were proposing to do-set up a mobile, clandestine radio station inside enemy territory and broadcast daily programs throughout the nation as an alternative to the progovernment media monopoly. The only other obvious example was Radio Rebelde (Rebel Radio) in Cuba. It had been set up in February 1958 by Che Guevara, who apparently came up with the idea after witnessing firsthand in Guatemala the devastating effectiveness of the CIA's use of radio propaganda in its overthrow of Pres. Jacobo Arbenz in 1954. From their secure zone in the Sierra Maestra, the Cuban revolutionaries established their radio station and broadcast daily on two shortwave frequencies. ${ }^{28}$ They broadcast their own news and variety shows as well as speeches against the Batista regime by Castro. The leaders even occasionally delivered coded orders to their troops, who carried radio receivers with them.

Although Radio Rebelde was neither mobile nor set up in the midst of enemy-controlled territory, its format resembles what Santiago and the Radio Venceremos team would create in El Salvador. However, Santiago claims that he did not use Radio Rebelde as a model, because he knew very little about it when he went to El Salvador. He only knew of its origins in the Cuban Revolution but had never heard the broadcasts from twenty years earlier, nor had he received advice or training from Cubans who had worked on Radio Rebelde. The only other example that Santiago mentioned when asked about possible models for what he was about to do in El Salvador was Radio Insurgente (Insurgent Radio), the Sandinista station set up shortly before Somoza's fall. But it was run out of an air-conditioned office in Costa Rica. ${ }^{29}$

So when he set out to create Radio Venceremos, Santiago only had vague models to guide him, and none of those were equivalent to the ERP's need for mobility inside enemy territory. In hindsight, we now know that what Santiago 
and Radio Venceremos accomplished was unprecedented. They eventually created a mobile FM radio unit that could broadcast throughout El Salvador and avoid the various detection and jamming devices aboard North American warships off El Salvador's coast. They did this for eleven years and went off the air for a combined total of only roughly one month, despite repeated army attacks, aerial bombardments, and the need to flee on various occasions. Regardless of anyone's political position in regard to El Salvador's civil war, the accomplishment of Santiago and Radio Venceremos is remarkable.

The ERP command considered it essential that the new radio station be up and running by the beginning of the first Final Offensive on January 10, 1981. The offensive, after all, was the incentive behind the creation of the station in the first place-to communicate with the general population about the guerrillas and their goals. Of course, the guerrillas hoped and believed that the First Offensive would topple the government, and so no one at the time knew that they were in for eleven long years of war.

Santiago did not arrive in El Salvador until late 1980, and neither he nor anyone else on his fledging radio team had any experience setting up a station from scratch under those clandestine conditions, especially with the mandate that the station be mobile. They had a lot to accomplish in a very short period of time. Santiago's memoir will reveal whether or not they managed to meet the deadline of the First Offensive, but one thing is certain: the conditions under which they set up the radio station were not going to get any easier as the war progressed. Until 1983 Morazán was still enemy territory, and so for almost two years Venceremos had to broadcast under the army's nose. And even after the army left the zone, the station faced the constant threat of army invasions and aerial bombardments.

Once Radio Venceremos was up and running, it quickly became a priority target for the army's High Command. Venceremos's ability to broadcast daily, even in the midst of military invasions into Morazán, became a source of constant embarrassment for the army. Listeners could sometimes hear battles raging in the background while Santiago and his team provided live reports. Furthermore, Radio Venceremos possessed the ability to be a weapon in the guerrillas' arsenal. While Venceremos dedicated most of its airtime to reporting news or providing entertainment, at times it became an agent in the guerrillas' campaign. On various occasions it called on the nation's populace to support particular resistance activities, such as transportation strikes, and the response was impressive. ${ }^{30}$

Venceremos had a wide audience, and Santiago's voice was easily the most recognized in the country. The army desperately wanted to get Radio Venceremos off the air, and so too did its North American supporters. To achieve that goal, it put its best man on the job, the notoriously brutal commander of the Atlacatl Battalion, Col. Domingo Monterrosa. 
Monterrosa pursued Venceremos with dogged determination. When I asked Santiago what it was like to live for eleven years as the army's priority target, he responded by saying that he did not remember the experience in those terms:

During the war I didn't really realize that we were such a target. I never really thought of it in those terms. I knew the army was directing the bulk of its energies against Chalatenango and Morazán. Indeed, the radio suffered many attacks, and we suffered deaths. I'll give you a recent example. I recently went to the doctor for a checkup and I had an X-ray done, and the doctor called me back and he was very concerned with what he saw, believing that I had cancer or something. But I had to assure him that in fact it was simply a piece of shrapnel that was still lodged in me that also gives me trouble when I pass through the airport metal detectors. ${ }^{31}$

With that response, Santiago might be engaging in a bit of humble selective memory, because what is apparent from his memoir is the army's relentless pursuit of the radio team and its equipment. One highlight of the memoir is the way in which the ERP commanders and the Venceremos team used the army's obsession to their advantage. Another interesting moment in the memoir is when the United States began using new surveillance technology that allowed it to pick up Venceremos's signal instantaneously and call in pinpointed air strikes. How Venceremos responded to this tactic will be revealed by the memoir.

Just as the army understood the importance of Radio Venceremos, so too did the guerrilla commanders. In the early stages of the war, the ERP included Venceremos in the command team, so Radio team members traveled everywhere with the ERP leadership and its security team. Altogether they numbered over one hundred. Following the shift in strategy to smaller units in late 1983 and early 1984, Venceremos traveled independently and was reduced in size to a core group of twenty-five.

But ERP leaders continued to place high priority on defending the radio station and making it possible for Santiago and his team to go on the air at the designated hour. The rest of the FMLN outside Morazán agreed on the value of Venceremos and were avid listeners. Eduardo Sancho, the commander of the RN on the Guazapa volcano recalls his troops diligently listening to Venceremos on small transistor radios. ${ }^{32}$ In 1982 the FMLN made Venceremos its official voice. This decision did not prevent the other main guerrilla faction, the FPL, from launching its own radio station, Radio Farabundo Martí, from its stronghold in Chalatenango in 1982. When asked about Radio Farabundo Martí, Santiago said that "it was our sister station; we worked closely with one another."33

The importance and value of Radio Venceremos were never more evident than in the case of the El Mozote massacre in December 1981. Santiago and the 
radio team were the first to arrive on the scene, two weeks after the military's departure. They were, subsequently, the first and, for a while, the only media source to report on the events that transpired there. Their reporting included the testimony of the sole surviving eyewitness, Rufina Amaya. The reporting of Venceremos inspired the New York Times and the Washington Post to send reporters to the scene, both of whom wrote front-page articles about what they saw. The collective reports by Venceremos and the U.S. newspapers caused great problems for the U.S. and Salvadoran governments, which tried to dismiss the story as guerrilla propaganda. ${ }^{34}$

Venceremos had a large audience, and even its enemies tuned in. Its news reports were more reliable than the progovernment sources. Its variety shows and soap operas were witty and engaging, as well as highly politicized. And for those listeners inclined toward the guerrillas, Santiago and the other voices on the radio were akin to celebrities. In the specific case of Santiago, the lead voice, no one knew what he looked like or who he was, which gave him a mystique, but his voice and charisma became legendary. In an interview, Leonor Márquez, a former guerrilla who worked on the Venceremos team between 1987 and 1989, recalled listening to Venceremos in the early 1980 os as a young girl in the Colomoncagua refugee camp in Honduras. She and all of her friends listened to Venceremos intently: "There was a mystique around the voices on the radio and the commanders who were being interviewed by them." She described it as "a great reward and surprise for me to be assigned to the radio" after she affiliated with the guerrillas in 1987. She described how the voices became real people, and Santiago in particular, the most famous of them all, proved to be an "honorable man who treated me like a daughter and always looked out for me." 35

When asked in 2008 about his time with Venceremos, Santiago said that he was very proud of what he did and what Venceremos accomplished. He said that it was hard work, that the days were long and taxing, but the reward came from the people he worked with, the cause they were fighting for, and the quality of work they produced:

After so much time, ten years [in the war zone], I would sometimes ask how long is this going to go on, I'm so tired of this, and for those of us from the city we would ask ourselves when I am ever going to get something as simple as a banana split? But in fact the work of the radio was really interesting and very satisfying, we wrote editorials, radionovelas [soap operas], we were very involved and dedicated to the struggle, and we saw that our work was of great importance to the struggle, and that's how we survived. And for those of us who came from the cities, this opportunity to live with the peasants of Morazán became a permanent education; we learned constantly from them, about such things as solidarity, sharing, and going hungry for 
days and still sharing what little you had, and perseverance and surviving such struggle. All this was very meaningful.

He also spoke about the grueling tragedy of war, about suffering so much loss and witnessing so such suffering. He pulled out a picture of the Venceremos team in 1981, some twenty-five people strong, and said that only three survived. But one of the things that gives him a sense of satisfaction even today is when people come up to him and say, "I know you, I know your voice, you're Santiago." 36

Although he was not born in El Salvador, he has become one of its adopted sons. He resides there currently and owns and directs a history museum. ${ }^{37}$ When people who knew Santiago during the war are asked about him during those times, they immediately comment on how well he integrated himself into the Salvadoran population and how much he embraced Salvadoran culture. As Miguel Ventura put it, "He was more Salvadoran than us Salvadorans."38

Santiago's appearance is anything but typical Salvadoran. He is tall, lightskinned, and cosmopolitan, terms that describe few peasants from northern Morazán. But he held the people of Morazán in high regard, and he firmly believed in the cause they were fighting for. In particular, he respected their tenacity, their willingness to survive, and their ability to devise survival strategies amidst the most challenging of circumstances. It is for this reason that he titled the Spanish version of his memoir La terquedad del izote. The izote is El Salvador's national flower, and one of its distinguishing characteristics is its hardiness. Seemingly, no matter what happens to the plant, it springs back to life, producing a beautiful white flower.

\section{The Memoir}

The memoir that you are about to read covers a span of four years, beginning with Santiago's departure from Nicaragua in late 1980 and ending in late 1984, when the military was launching yet another full-scale invasion of northern Morazán. The memoir is structured in the form of a journal, with dates preceding entries. But progressing through it, the events contained in those four years have a natural novel-like quality to them, with a crisis and resolution.

The original journal that Santiago kept and that would have become this memoir was destroyed by the army in early 1984. During one of the many instances in which the radio team had to flee, Santiago left his journal behind. He buried it in a shallow hole as he was leaving, but soldiers found it and burned it. A guerrilla who later arrived on the scene brought the charred remains to Santiago. The loss of his journal caused Santiago to go into a depression, but as was usually the case among the guerrillas in Morazán, the community responded to alleviate individual pain. The radio team told Santiago that they would work with him to

xl BROADCASTING THE CIVIL WAR IN EL SALVADOR 
reconstruct his journal, and so they collectively sat down for extended sessions of recollection. As good journalists they also gathered stories from people who had appeared in the original. Thus, the text you have before you is as true to the original as Santiago felt he was able to achieve, but it is also a necessarily collective effort grown out of the reality of loss.

The following memoir/journal cannot be identified as a "testimonial." Testimonials are by definition a specific genre of Latin American literary production. They are the first-person narrative of an otherwise disenfranchised or illiterate person who tells her or his story to a literate outsider who then uses international contacts to get it published and distributed. ${ }^{39}$ One of the most well known testimonials is I, Rigoberta Menchú, the story of a young indigenous woman from the highlands of Guatemala who told her story to a French anthropologist in the early 1980 os. In telling her story, Menchú narrated the broader experiences of Guatemala's indigenous peoples who were suffering from the government's scorchedearth practices. ${ }^{40}$ As a literate, educated Venezuelan trained in journalism, Santiago does not fit the standard description of a testimonial source. Nevertheless, there have been so few firsthand accounts from the war zones in El Salvador that the following work assumes something of a testimonial quality, particularly given that it was produced collectively by fellow guerrillas, some of whom were poor, illiterate peasants from Morazán. The work might also fall under the category of memoir, war journal, or even a collaborative life narrative. ${ }^{41}$

As mentioned earlier, the memoir is at once a very personal, individual reflection, but also it tells a broader story of an entire group of people, and even an entire war. There are some aspects of the memoir that might seem mundane at first glance, but they will assume significance on reflection. One such example is the detailed description of weapons and supplies being captured from the enemy. In providing these details, Santiago reveals much about the nature of the guerrillas in Morazán. The guerrillas' enemies, including the U.S. government, portrayed them as underlings of international communists, who supposedly provided the guerrillas with ample supplies and sophisticated weaponry. Santiago's description refutes this argument. He shows how much a single rifle or a few supplies meant to them, so much that, even amidst all the drama, a few rifles and some ammunition merited detailed reference. ${ }^{42}$

Another aspect that might surprise readers at first glance is the number of people who appear in the text. Santiago's story literally involves a cast of hundreds, including fellow guerrillas, enemy soldiers, international personages, and historical figures. I lost count at three hundred when I tried to keep track of the individuals who are mentioned. Here again is an opportunity to gain insight into the guerrilla movement. The guerrillas were team members who lived together, formed lifelong friendships, and relied on one another for survival. Each of them had made a personal choice to join the guerrillas, which meant leaving 
their families, making great sacrifices, and facing death, perhaps even by torture if captured alive. Fellow guerrillas became one's community. Sometimes a group of guerrillas served together for many years. Other times, they entered and left one another's life with surprising rapidity. Many of the people mentioned by Santiago died or were captured and disappeared in army prisons. By naming them he honors their sacrifice.

The pace of these social interactions and the entrance and departure of individuals throughout the text is sometimes frenetic, especially during pitched battles. Santiago usually identifies fellow guerrillas by their singular nom de guerre, although he sometimes provides people's real names. But it is apparent throughout the memoir that, for all the numbers of people he mentions, Santiago is not careless with his references. He carefully fits them into a narrative structure, at times allowing their life stories to edify certain issues or answer broader questions, like why the guerrillas were fighting, or what it was like to have been born a peasant in Morazán.

What is also apparent from the memoir is the infrequency of combat and the amount of time spent engaging in noncombat activities. Even though the fighting in Morazán was intense, four years is a long time, and many more days passed without combat than with it. In the interim, there was much work to do, but it was also a time for people to live their lives with one another. Santiago's memoir provides us with a look into the daily life of a population in a war zone in between battles.

Ultimately, Santiago's memoir is a very human story. It describes a group of people banded together to fight against overwhelming odds for a cause they believed in. Most of those people did not survive. Those who did were left to mourn their losses but also to reap the rewards of the sacrifices. What follows is Santiago's story, and theirs.

\section{NOTES}

1. Ronald Reagan, Address to the Nation on the United States Policy in Central America, May 9, 1984, http://www.reagan.utexas.edu/archives/speeches/1984/50984h .htm.

2. United Nations, Commission on Truth, From Madness to Hope: The Twelve Year War in El Salvador, Report on the Commission of the Truth for El Salvador (New York: United Nations Security Council, 1993).

3. For descriptions of Morazán, see Leigh Binford, "Grassroots Development in Conflict Zones of Northeastern El Salvador," Latin American Perspectives 24:2 (March 1997): 56-79; idem, "Hegemony in the Interior of the Revolution: The ERP in Northern Morazán, El Salvador," Journal of Latin American Anthropology 4:1 (1999): 2-45; idem, "Peasants, Catechists and Revolutionaries: Organic Intellectuals in the Salvadoran Revolution, 1980-1992," in Aldo Lauria and Leigh Binford, eds., Landscapes of Struggle: Politics, 
Society and Community in El Salvador (Pittsburgh: University of Pittsburgh Press, 2004), pp. 105-125.

4. Binford, "Hegemony in the Interior," p. 11.

5. Francisco Mena Sandoval, Del ejército nacional al ejéricto guerrillero (San Salvador: Ediciones Arcoiris, 1990). See also Marcelo Cruz Cruz, "La conspiración revolucionaria dentro de la Fuerza Armada," in Stefan Ueltzen, Conversatorio con los hijos del siglo (San Salvador: Editorial III Milenio, 1994).

6. The literature on theories of peasant revolutions is vast, but one work that puts the question succinctly is by Craig Jenkins, "Why Do Peasants Rebel? Structural and Historical Theories of Modern Peasant Rebellions," American Journal of Sociology 88:3 (November 1982): 487-514. Works that engage the subject with particular regard to El Salvador include Timothy Wickham-Crowley, Guerrillas and Revolution in Latin America: A Comparative Study of Insurgents and Regimes since 1956 (Princeton: Princeton University Press, 1992); Jeffery Paige, Coffee and Power: Revolution and the Rise of Democracy in El Salvador (Cambridge: Harvard University Press, 1997); Yvon Grenier, The Emergence of Insurgency in El Salvador (Pittsburgh: University of Pittsburgh Press, 1999); and Thomas David Mason, Caught in the Crossfire: Revolutions, Repression and the Rational Peasant (Lanham, Md.: Rowman and Littlefield, 2004). In a fascinating study, Elizabeth Jean Wood emphasizes the importance of emotion and the sense of personal reward that comes with collective action as a variable in explaining individual or community participation in an insurgency; see Insurgent Collective Action and Civil War in El Salvador (Cambridge: Cambridge University Press, 2003).

7. Binford, "Peasants, Catechists and Revolutionaries," pp. 112-113.

8. José Inocencio Alas, Iglesia, tierra y lucha campesina: Suchitoto, El Salvador, 1968 1977 (San Salvador: Asociación de Frailes Franciscanos, 2003). See also Binford, "Peasants, Catechists and Revolutionaries."

9. Interview with Miguel Ventura, April 16, 2008, Ciudad Segundo Montes.

10. Ibid.

11. The word choice in this sentence requires explanation. To say, "the peasants responded" to Arce Zablah's call to form military committees implies that Arce Zablah and/or other ERP guerrilla leaders possessed agency and the peasants followed passively. Any reader familiar with debates over the origins of revolutionary movements will recognize the contentious nature of that claim. I chose to leave the language as is in the absence of significant contrary evidence in the case of Morazán; see the previously cited works by Leigh Binford. But as one example of an alternative, Héctor Lindo and I conducted an interview with a former peasant organizer around Suchitoto who joined the guerrillas in the late 1970s. He says that he and his fellow peasants formed a military committee independently and then sought out a formalized guerrilla organization to support their initiative. They eventually joined the RN (interview with Fidel Recinos, aka Raúl Hercules, June 19, 2009, in the Ministerio de Seguridad Pública, San Salvador). We elaborate on that interview in Modernizing Minds (working title), forthcoming from the University of New Mexico Press.

12. Binford, "Peasants, Catechists and Revolutionaries," pp. 121-122. Binford bases his 
conclusions on, among other sources, interviews with Miguel Ventura. I also interviewed Miguel Ventura in Segundo Montes on April 16, 2008, and then again on November 6, 2008. See also Tommie Sue Montgomery, Revolution in El Salvador: From Civil Strife to Civil Peace (Boulder, Colo.: Westview Press, 1995), pp. 120-121, in which she argues the same based on interviews with Comandante Balta of the ERP.

13. For a good example of the hardships facing underground militants, see Claribel Alegría's biography of FPL member Eugenia, They Won't Take Me Alive: Salvadoran Women in the Struggle for Liberation (London: Women's Press, 1987). See also the letters from ERP cofounder Lil Milagro Ramírez to her family, including "Carta de Lil Milagro Ramírez, en la que explica las razones que la obligaron a clandestinizarse," El Diario de Hoy, July 14, 2003; all of the letters were printed in Diario CoLatino in 2003. For just one example of actions by state agents, see Nidia Díaz's memoir, I Was Never Alone: A Prison Diary from El Salvador (Melbourne: Ocean Press, 1992). For a comprehensive catalog of abuses committed during the war, see United Nations, From Madness to Hope.

14. See the memoir of RN founder, Eduardo Sancho, Crónicas entre los espejos (San Salvador: Editorial Universidad Francisco Gavidia, 2002).

15. Binford, "Peasants, Catechists and Revolutionaries."

16. Interview with Miguel Ventura, April 16, 2008, Ciudad Segundo Montes.

17. Interview with Julio Flores, July 17-18, 2007, San Salvador.

18. Binford, "Grassroots Development," pp. 58-59, citing Mena Sandoval, Del ejército nacional, pp. 201-207.

19. Each of the five guerrilla organizations of the FMLN retreated to rural areas where they had previous contacts. So the ERP went to Morazán, the FPL to Chalatenengo, the RN and the PCS to the Guazapa Volcano, and the PRTC to San Vicente. As the war evolved into a protracted rural insurrection, these five groups and their respective fronts functioned at once in a coordinated effort and also as a series of five distinct movements with their own dynamics and logistics. While some research has been done on the subject of the internal functioning of the FMLN, much remains to be told.

20. Binford, "Grassroots Development," pp. 61-62. See also Jenny Pearce, Promised Land: Peasant Rebellion in Chalatenango, El Salvador (London: Latin American Bureau, 1986).

21. On El Mozote, see Mark Danner, The Massacre at El Mozote (New York: Vintage, 1994); and Leigh Binford, The El Mozote Massacre: Anthropology and Human Rights (Tucson: University of Arizona Press, 1996).

22. The Villalobos quotation is from Max G. Manwaring and Court Prisk, El Salvador at War: An Oral History of Conflict from the 1979 Insurrection to the Present (Washington, DC: National Defense University Press, 1988), p. 147. See also David Spencer, From Vietnam to El Salvador: The Saga of the FMLN Sapper and Other Guerrilla Special Forces in Latin America (Westport, Conn.: Praeger, 1996), p. 106. For the military's pulling back after the 1984 attack on San Miguel barracks, see José Ángel Moroni and David Spencer, Strategy and Tactics of Salvadoran FMLN Guerrillas: Last Battle of the Cold War, Blueprint for Future Conflicts (Westport, Conn.: Praeger, 1995).

23. Spencer, From Vietnam to El Salvador, p. 95. See also Moroni and Spencer, Strategy and Tactics.

24. Author interview with Marisol Galindo, April 17, 2008, Perquín. 
25. For one example, see Jack Hammond, Fighting to Learn: Popular Education and Guerrilla War in El Salvador (New Brunswick: Rutgers University Press, 1998).

26. This first radio endeavor is described in José Ignacio López Vigil, Rebel Radio: The Story of Radio Venceremos (Willimantic, Conn.: Curbstone Press, 1994), pp. 4-11, first published in Spanish as Las mil y una historias de Radio Venceremos (San Salvador: UCA Editores, 1993), pp. 13-34.

27. The information for this biographical section on Santiago is derived from a series of interviews with him, April 4, April 8, and October 24, 2008, all in San Salvador.

28. Http://www.pateplumaradio.com/central/cuba/rebel1.html.

29. For those readers interested in the importance of radio and media outlets in mass protest/insurrectionary movements, the 2006 uprising in Oaxaca, Mexico, provides a vivid example. See the documentary Un poquito de tanto verdad (A little bit of so much truth), Corrugated Films, 2007.

30. One of the ways the FMLN gained compliance with their demands for transportation strikes was to burn busses that were found operating during the hours of the strike. Such acts were controversial, given that the patrons of the busses (generally poor civilians) were deprived of transportation, but the owners of the bus companies were mostly military officers or men closely allied to the military regime.

31. Interview with Santiago, April 8, 2008, San Salvador.

32. Interview with Eduardo Sancho, April 8, 2008, San Salvador.

33. Interview with Santiago, April 8, 2008, San Salvador.

34. Danner, The Massacre at El Mozote; and Binford, The El Mozote Massacre.

35. Interview with Leonor Márquez, April 19, November 5, 2008, Perquín.

36. Interview with Santiago, April 8, 2008, San Salvador.

37. El Museo de la Palabra y la Imagen: http://www.museo.com.sv/index.php?op tion $=$ com_frontpage $\&$ Itemid $=1$.

38. Interview with Miguel Ventura, April 16, 2008, Ciudad Segundo Montes.

39. See, for example, Francesca Denegri, “Testimonio and Its Discontents," in Stephen Hart and Richard Young, eds., Contemporary Latin American Cultural Studies (London: Arnold, 2003).

40. Rigoberta Menchú, I, Rigoberta Menchú: An Indian Woman in Guatemala (London: Verso, 1984). For the debate over the Menchú testimony, see Arturo Arias and David Stoll, The Rigoberta Menchú Controversy (Minneapolis: University of Minnesota Press, 2001).

41. See Sidonie Smith and Julia Watson, Reading Autobiography: A Guide for Interpreting Life Narratives (Minneapolis: University of Minnesota Press, 2001). Because of the collaborative nature of Santiago's text, variations of some of its stories have appeared in other collections from the Radio Venceremos team. See, for example, José Ignacio López Vigil, Rebel Radio, and its Spanish version, Las mil y una historias de Radio Venceremos.

42. The origins of the FMLN's weaponry was a hotly contested issue. The FMLN's adversaries, including the U.S. government, insisted that Russia, Cuba, and Nicaragua were the suppliers. The guerrillas countered these accusations by emphasizing the local origins of their weaponry and its purchase on the international black market, in large part with funds raised from civilian donations in the United States and Western Europe. 
There is no doubt that weapons came from Vietnam, Cuba, and Nicaragua. For example, research shows that Vietnam sent U.S. weapons that had been captured from the South Vietnamese forces after 1975. As always, the question remains about the proportions of weapons from foreign sources compared to local sources and black-market purchases. Santiago emphasizes the local sources, although, to his credit, some researchers insist that foreign sources increased only after 1984, where the present book ends. For one study on the debate, see Dirk Kruijt, Guerrillas: War and Peace in Central America (London: Zed Books, 2008), pp. 84-85. 


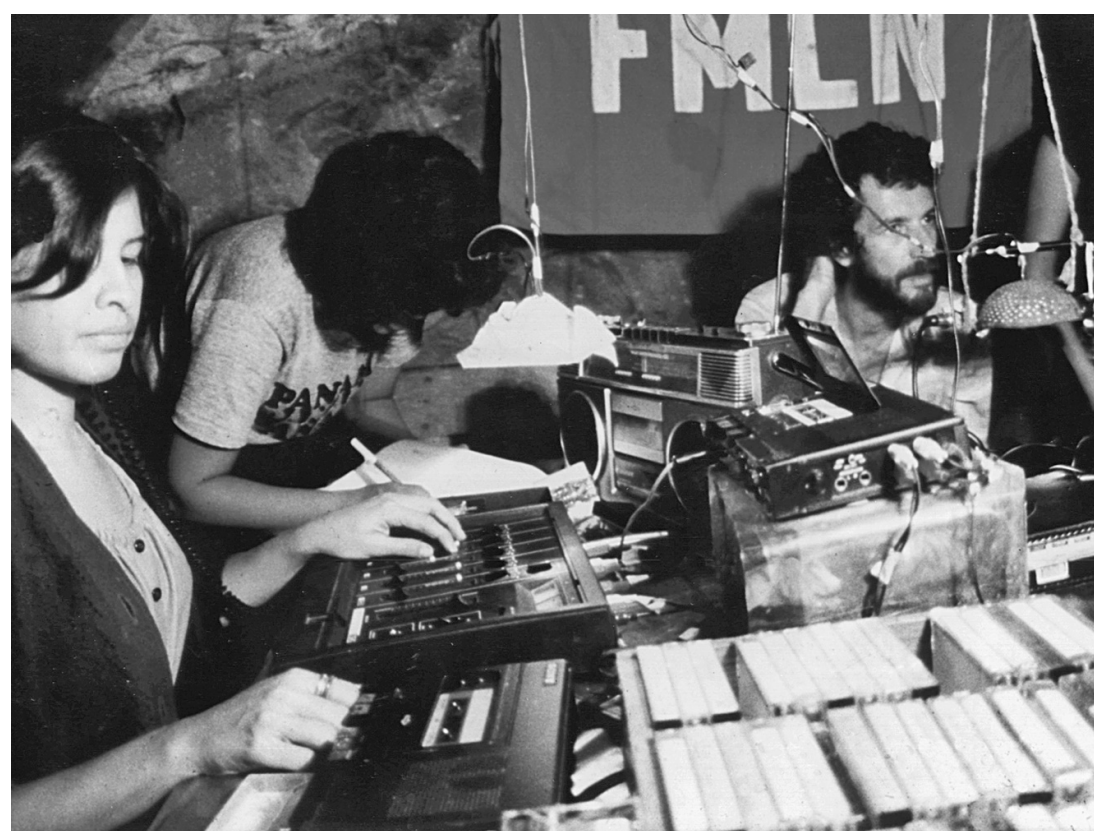

In the "Passion Cave." Marcela (far left) looks like a princess piloting a spaceship.

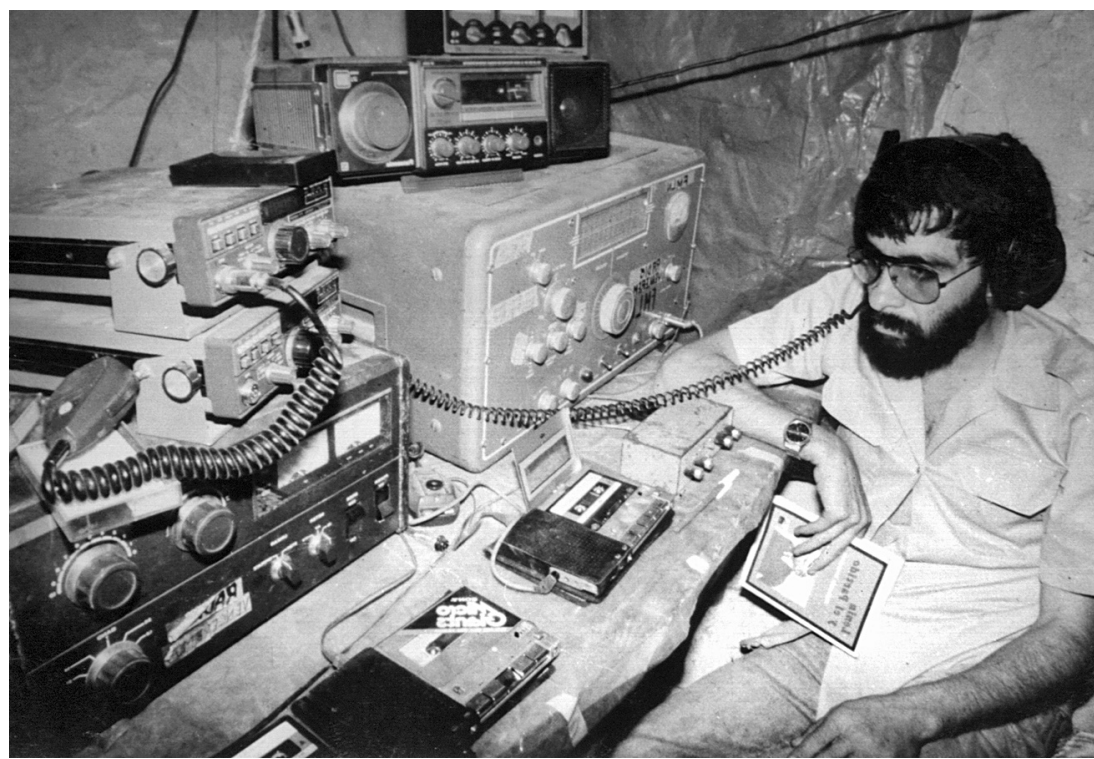

Genaro monitoring the transmitter. 


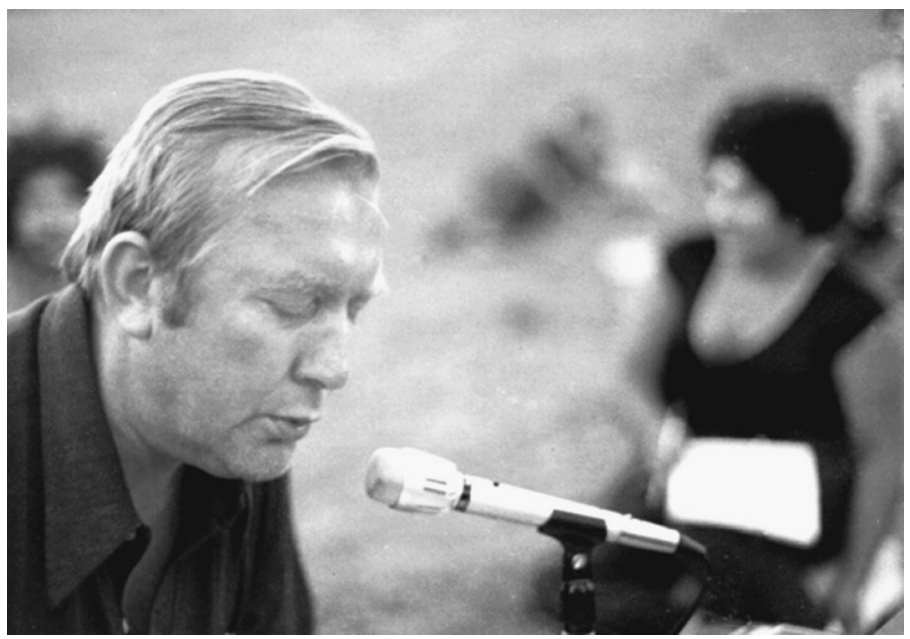

January 1981-Father Rogelio Ponseele at the microphone during one of Radio Venceremos's first transmissions.

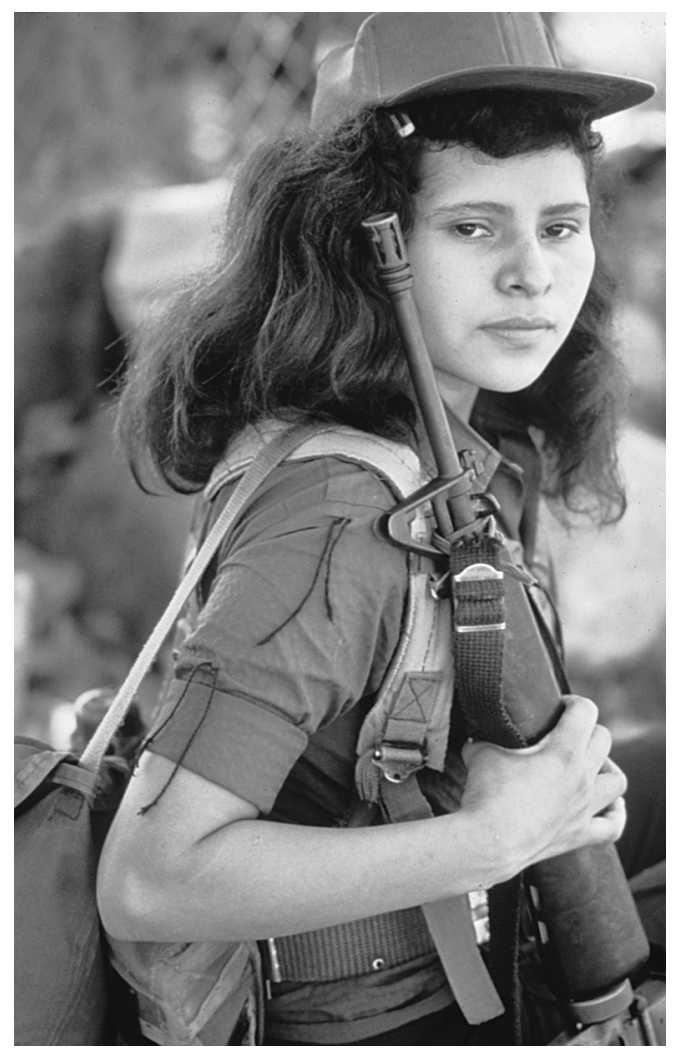

Emely's look brought a reassuring softness to insurgent radio. 


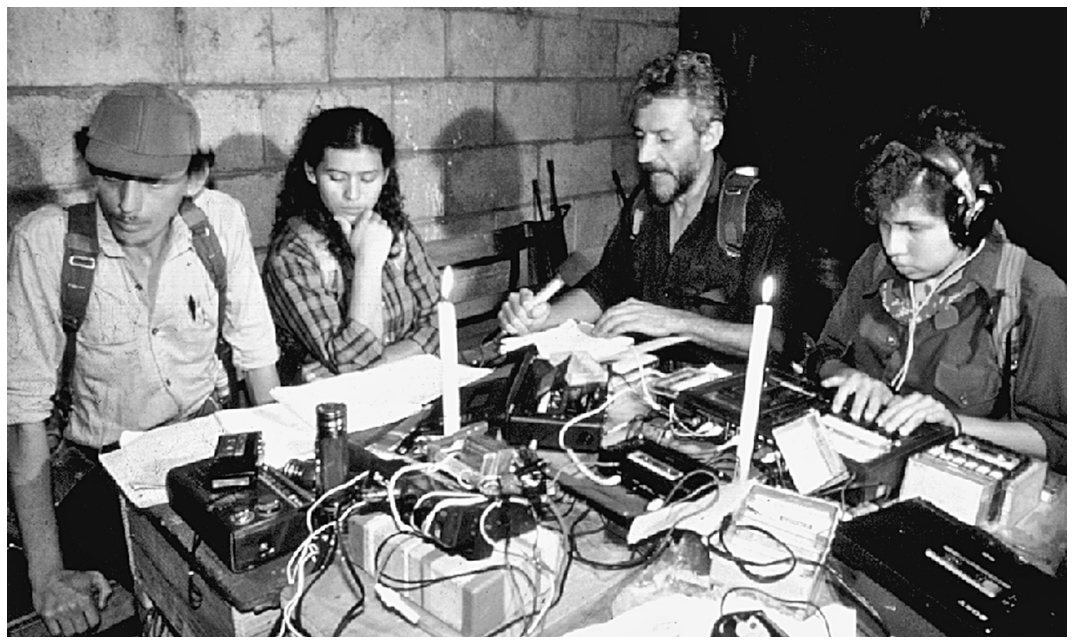

Transmitting by candlelight. From left to right: Marvin, Lety, Santiago, and Ana Lidia.

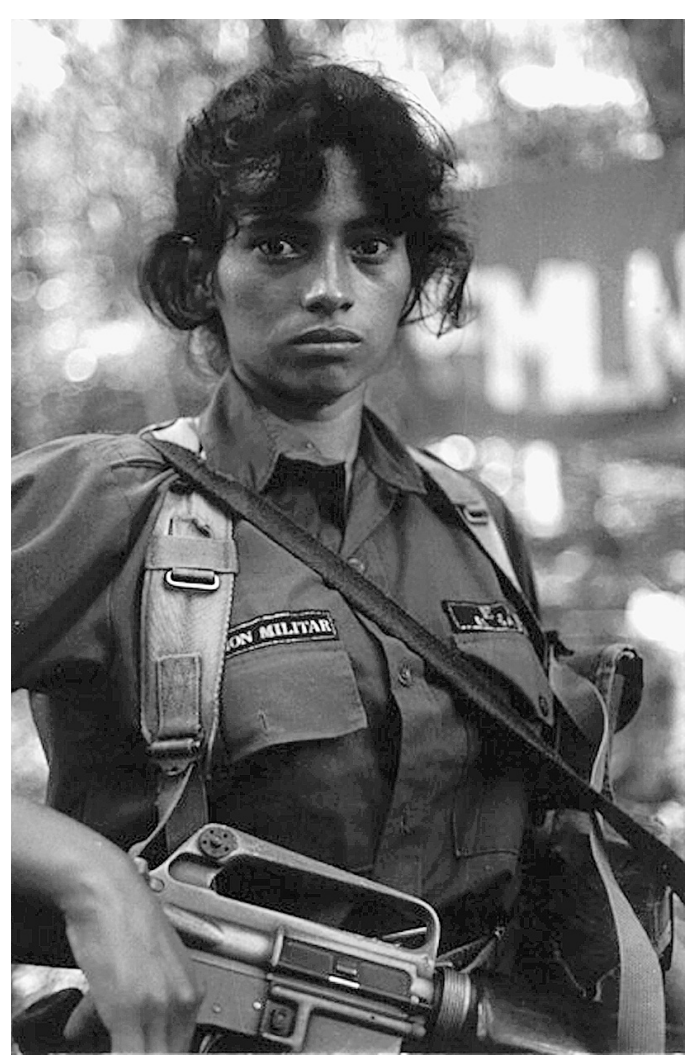

A young guerrilla fighter from Morazán. 


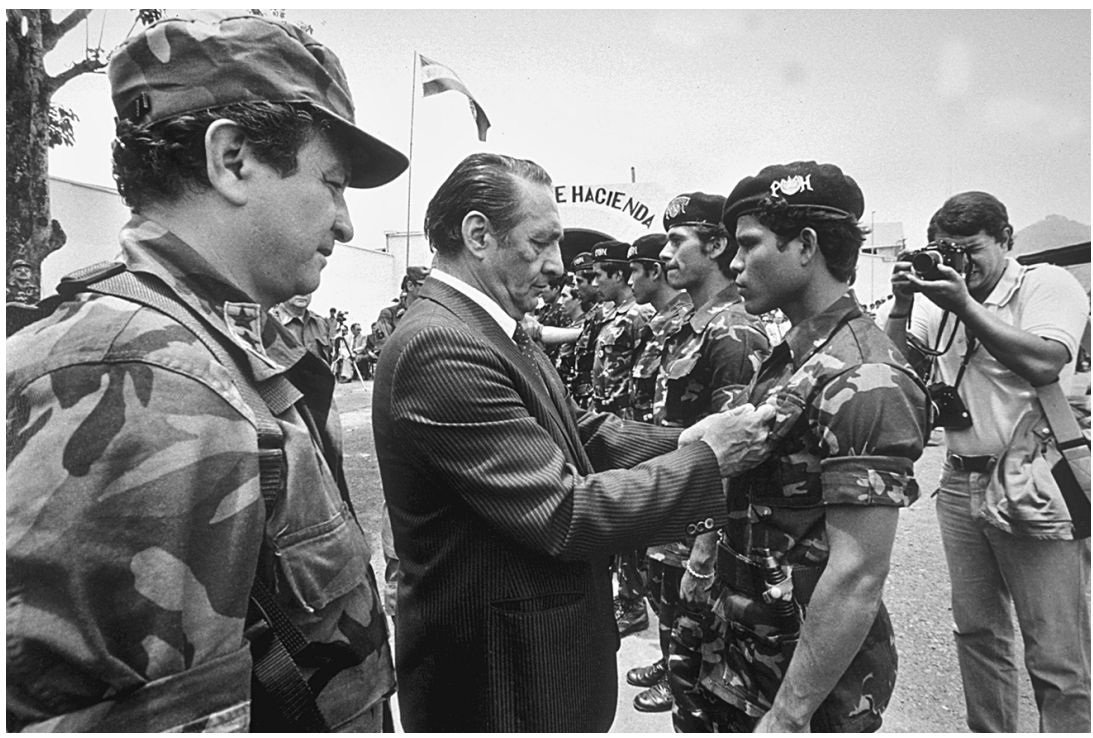

Gen. Adolfo Blandón and Pres. José Napoleón Duarte.

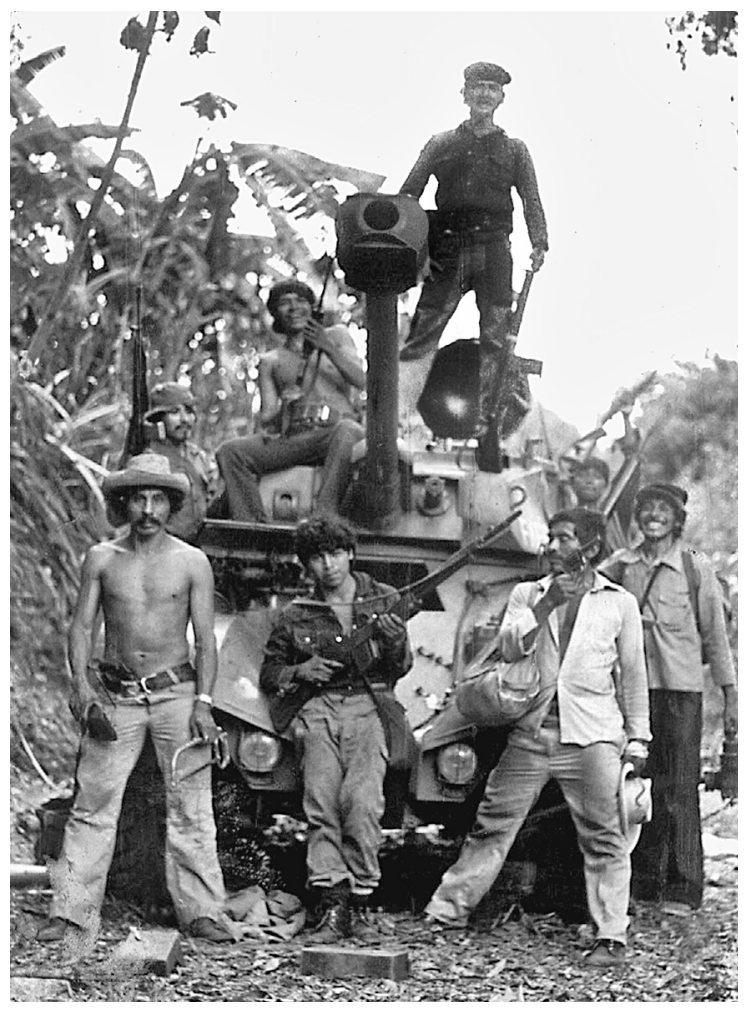

Guerrillas with a captured tank in the Guazapa zone. 


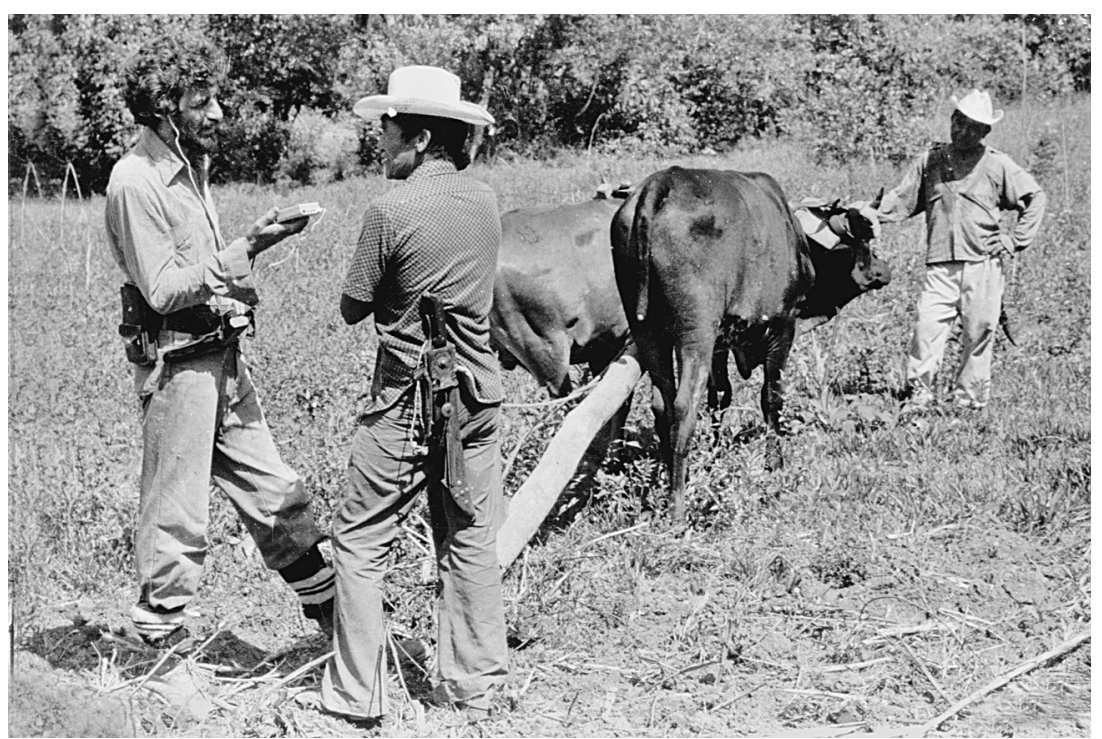

Santiago interviewing peasants.

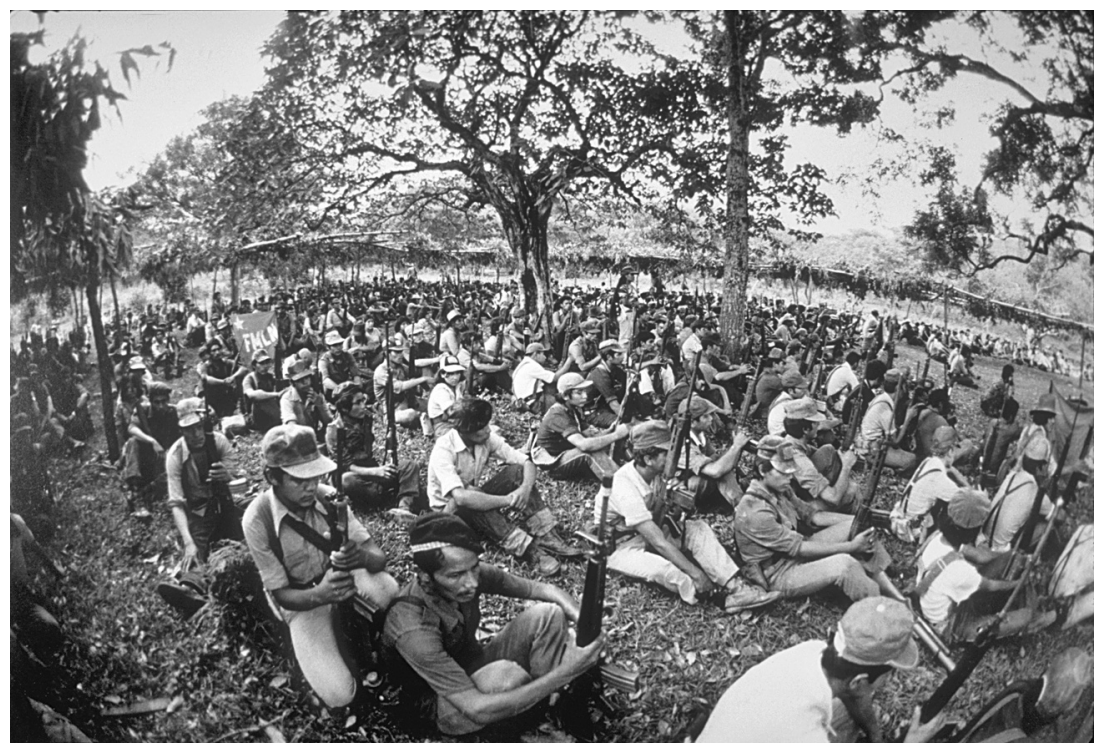

A guerrilla concentration, June 1981. 


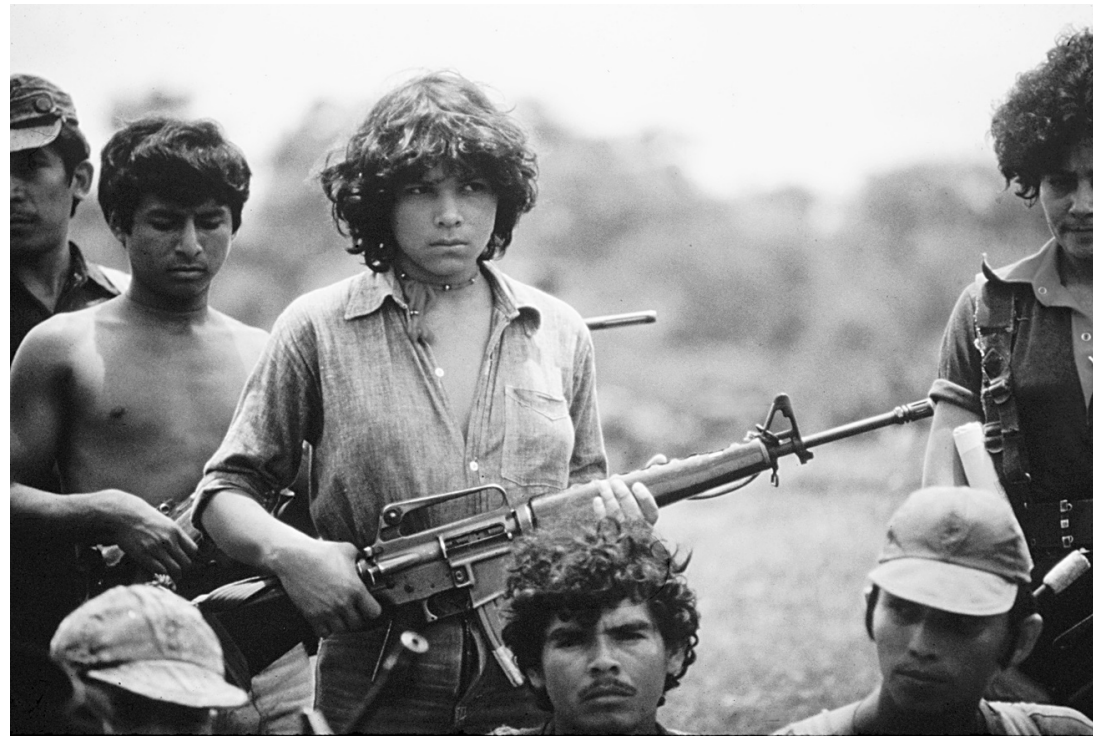

Claudia, whose story floods our memories.

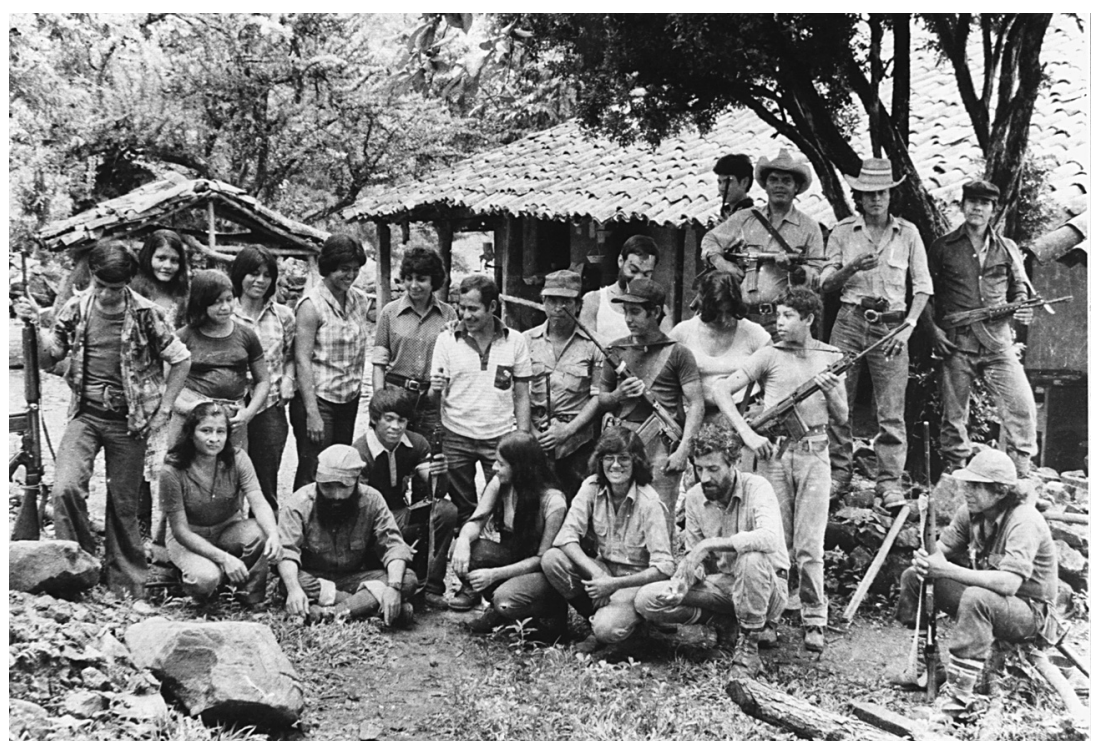

The Radio Venceremos team at the beginning of 1982. Many of those pictured here did not survive the war. 


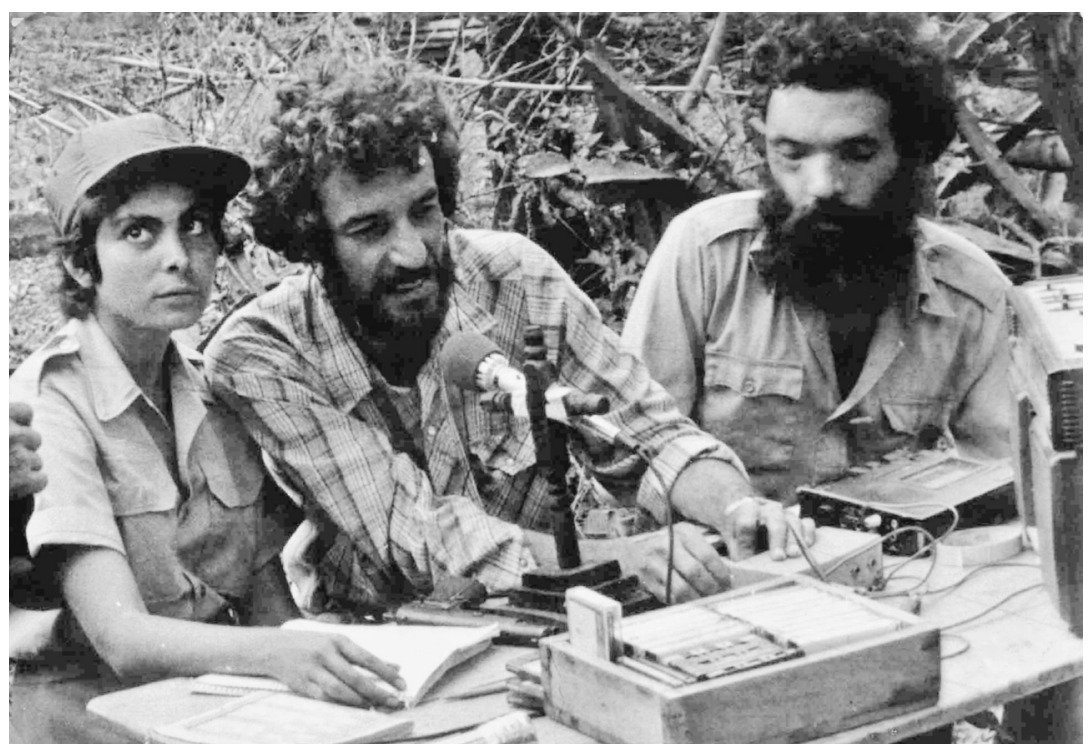

Mariposa, Santiago, and Maravilla during the occupation of Villa del Rosario in 1981.

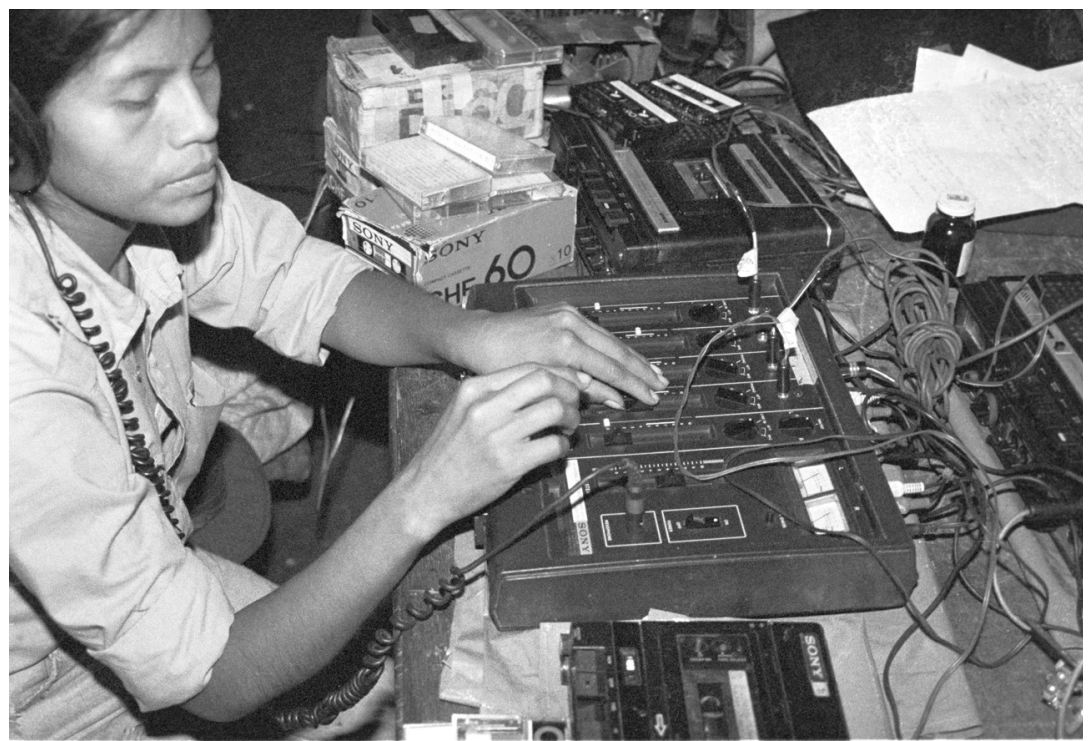

Cecilia, a member of the team that monitored foreign news broadcasts. 


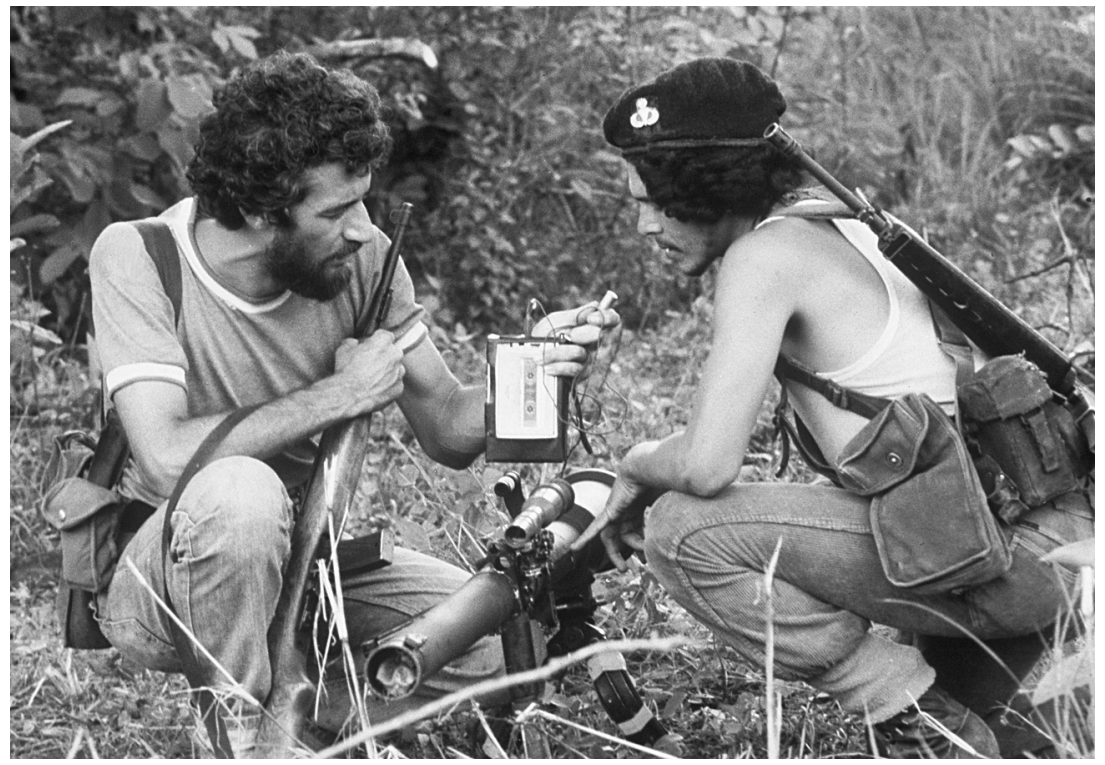

Santiago interviewing a guerrilla combatant.

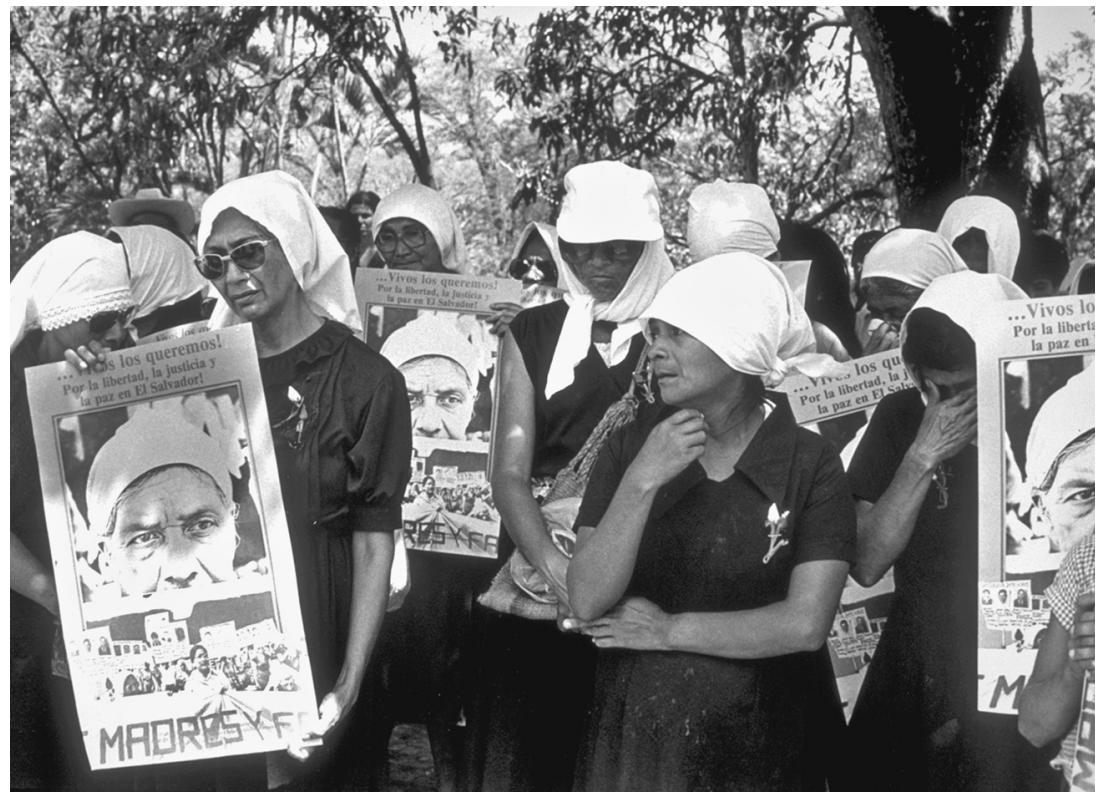

Mothers of disappeared political prisoners marching to demand information about their loved ones. 


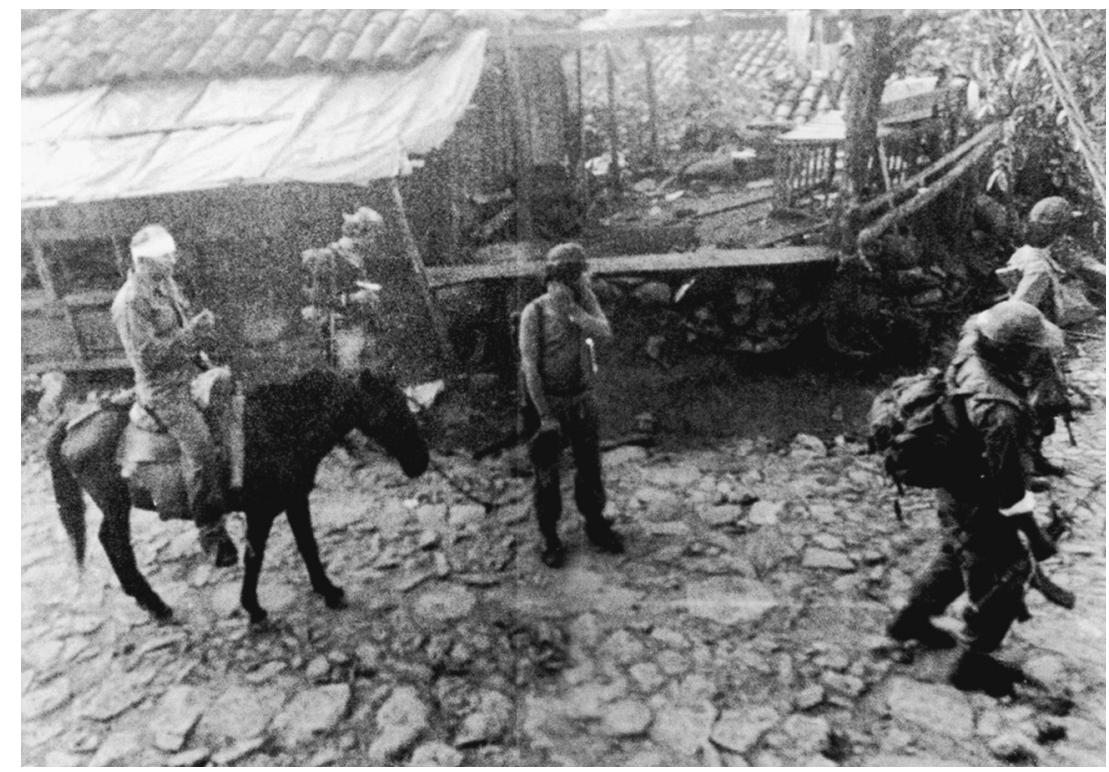

Gen. Francisco Castillo, vice minister of defense, shown here shortly after his capture following the downing of his helicopter during the Battle of Moscarrón, 1982.

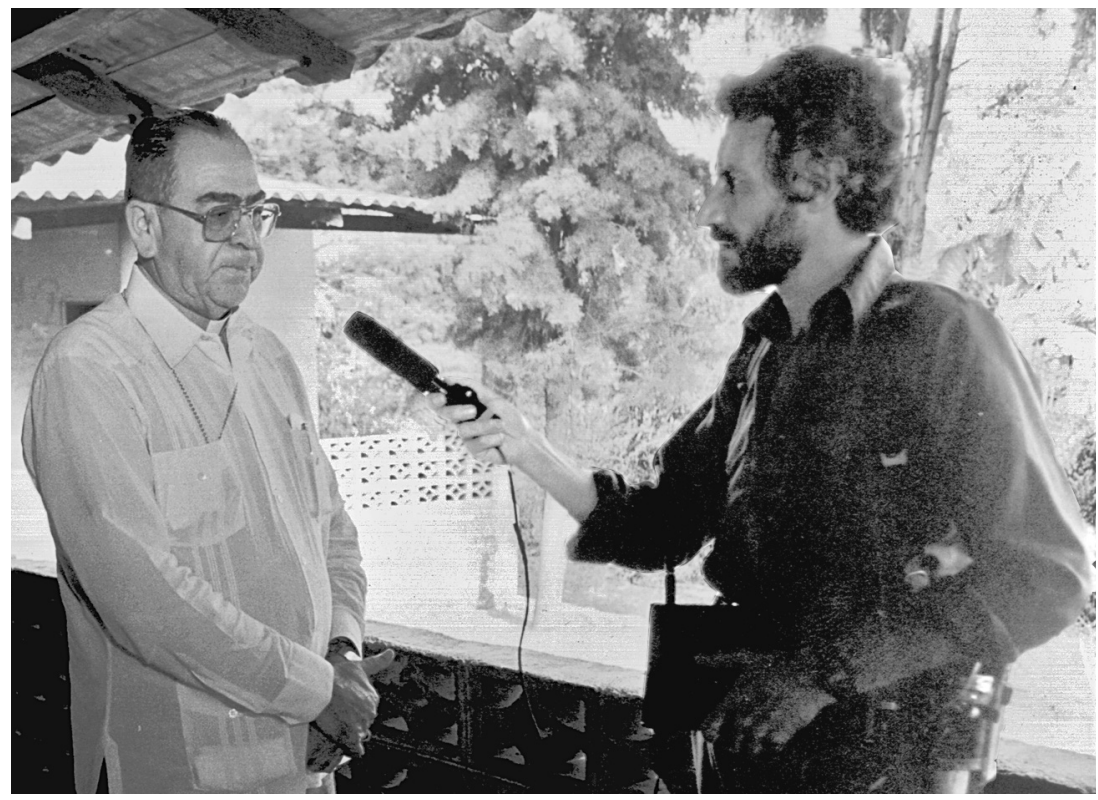

Monsignor Rivera y Damas being interviewed by Santiago during the archbishop's visit to Perquín. He witnessed captured government soldiers being turned over to the Red Cross. 


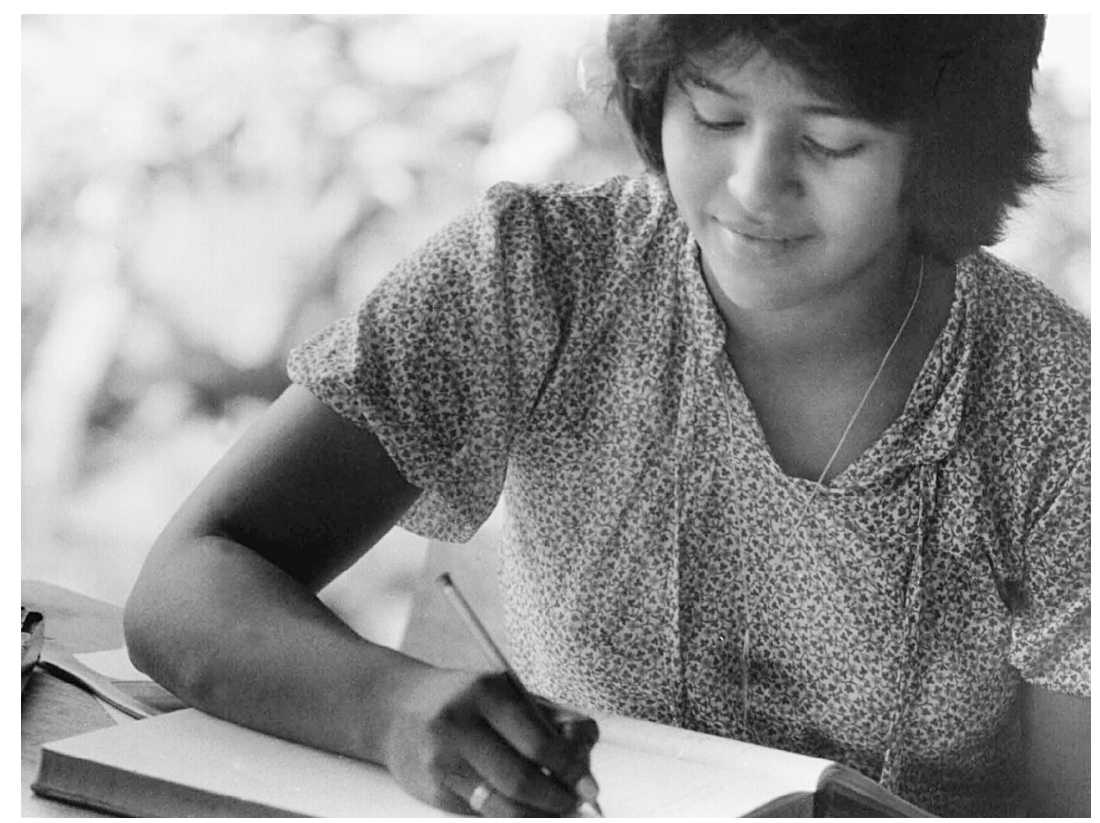

Mabel, one of the pioneers of Radio Venceremos. Her death in Joateca weighs heavily on our souls.

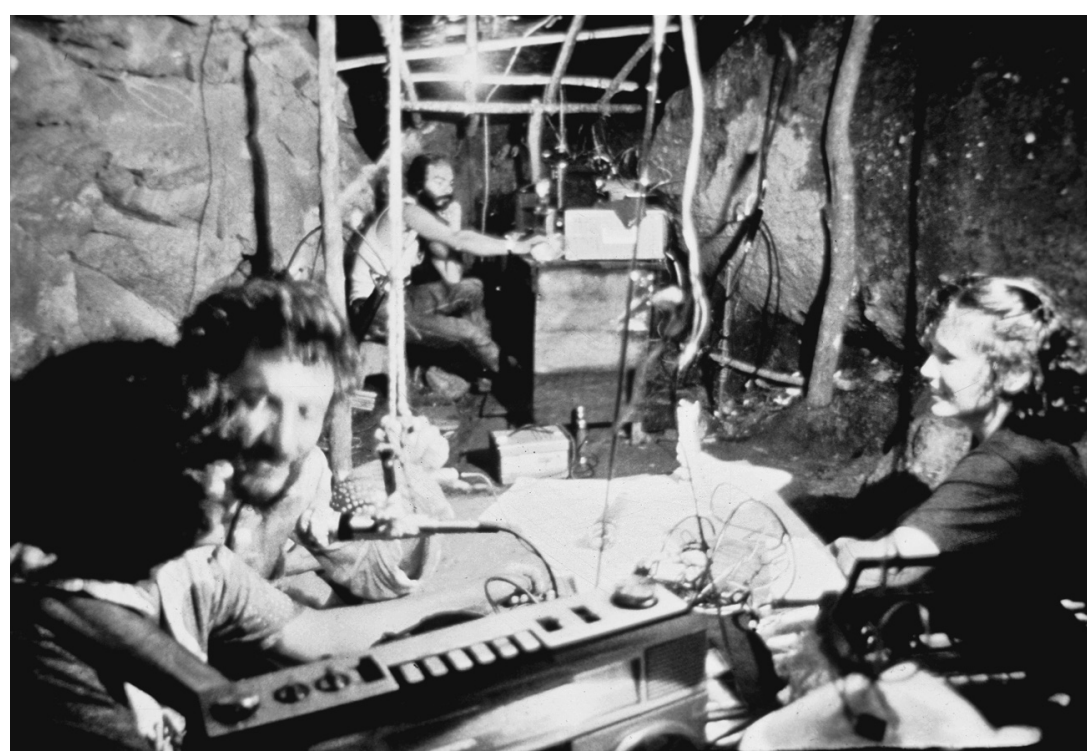

Inside the "Passion Cave." 


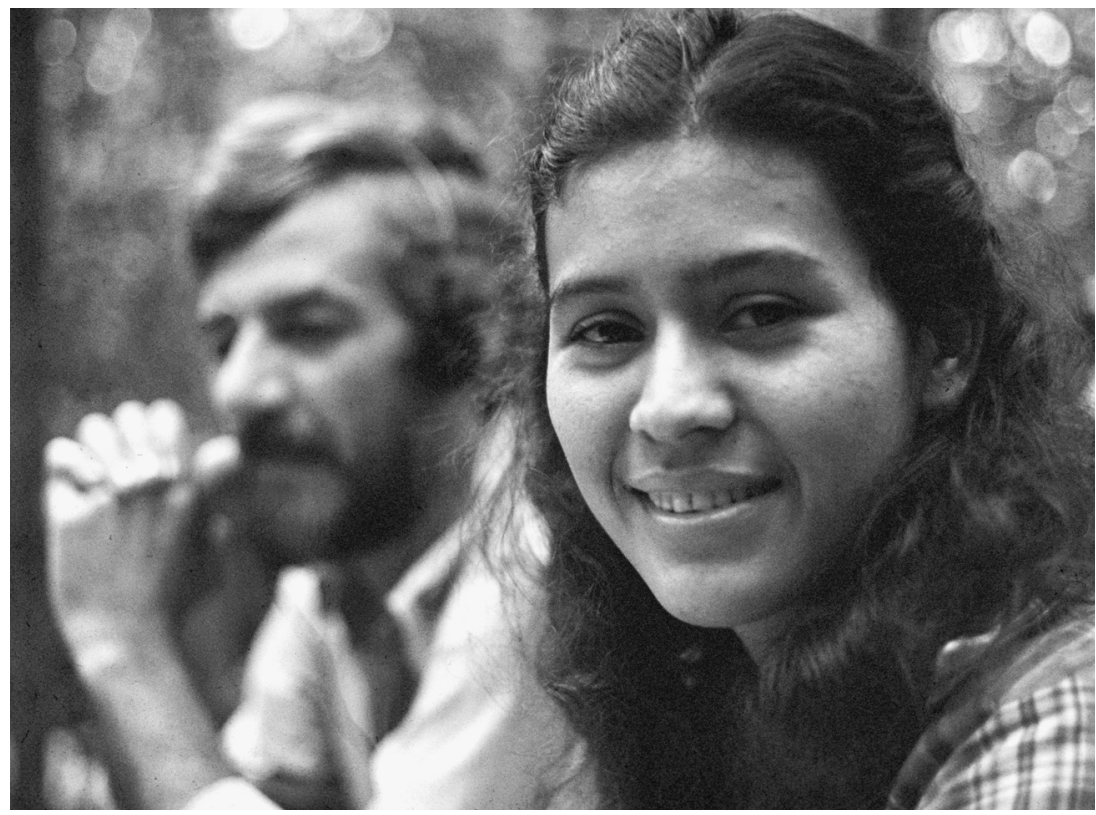

Lety's smile. She was a radio announcer and also responsible for political affairs in the camp.

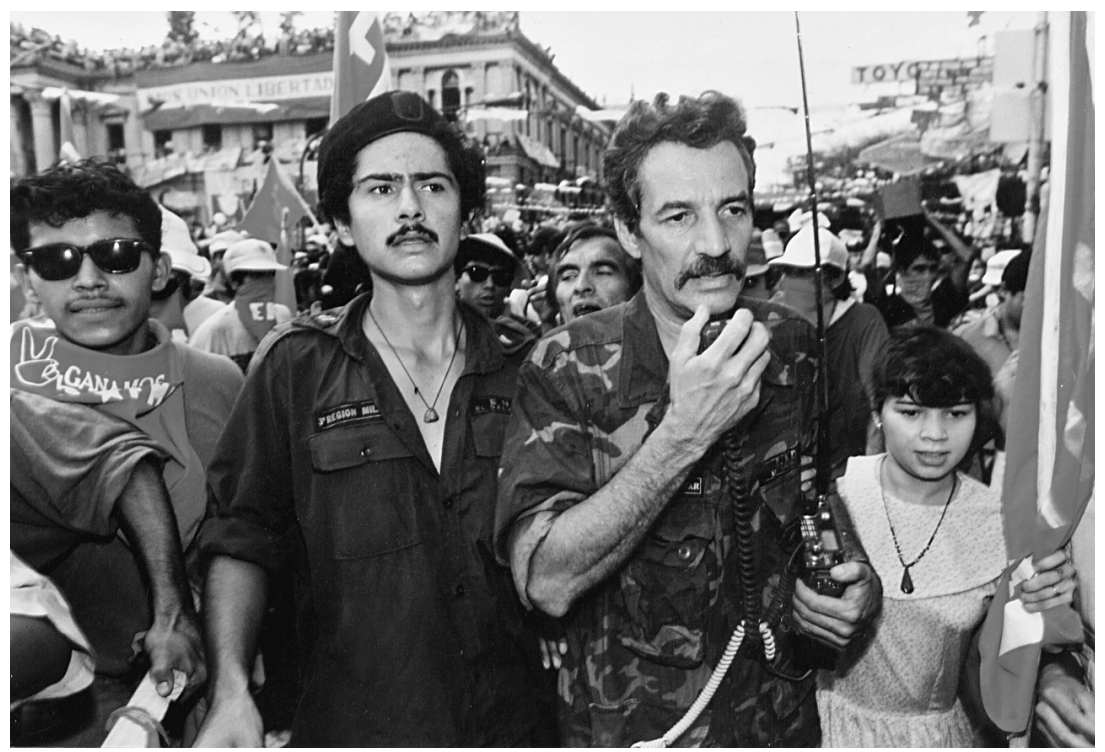

Santiago entering the capital city of San Salvador on January 16, 1992, the day the Peace Accords were signed. 


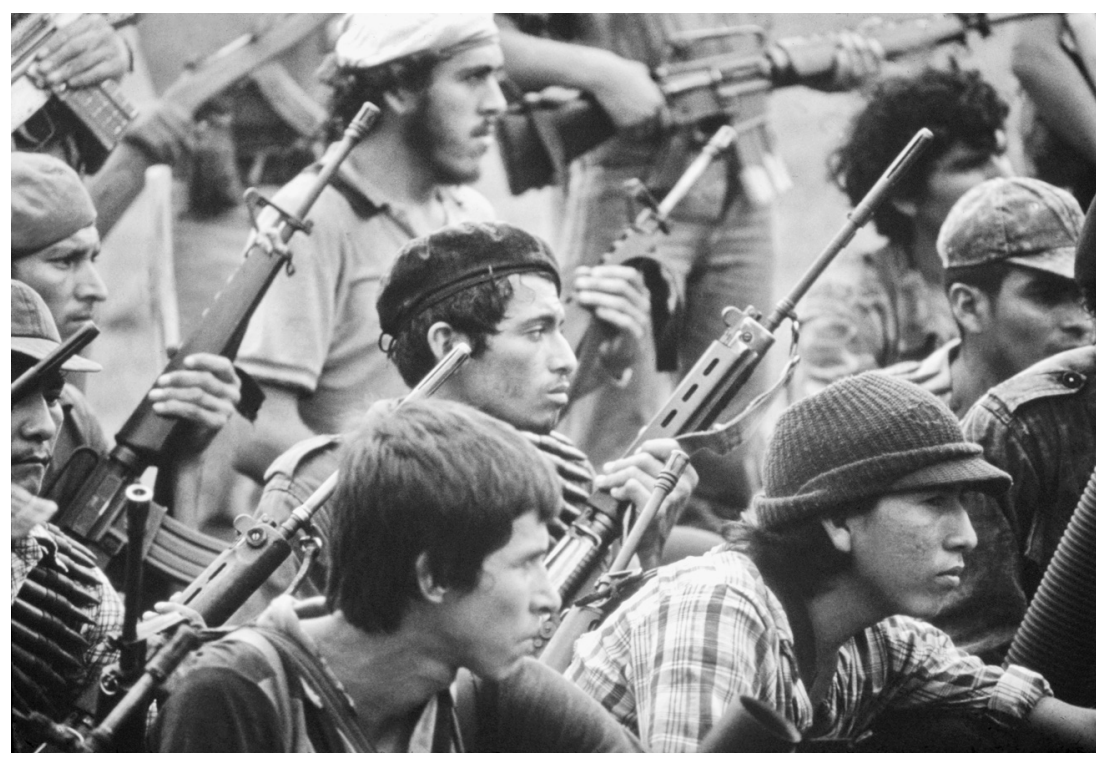

Guerrilla combatants preparing for the Battle of Moscarrón, 1982.

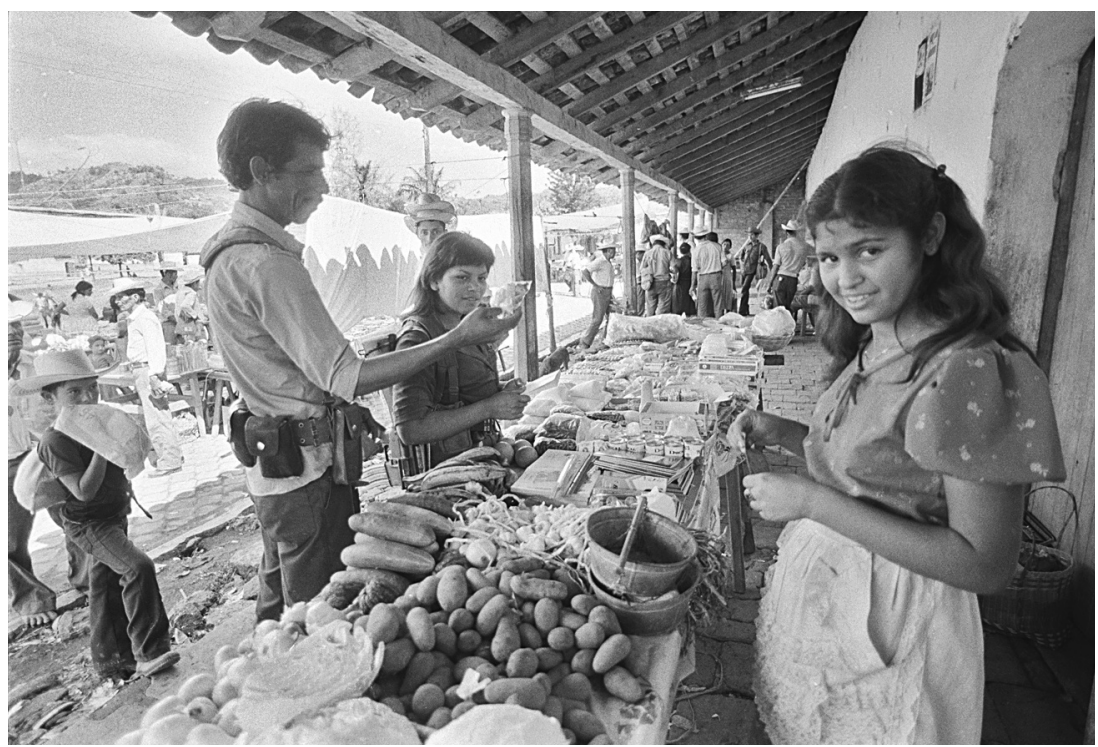

Guerrilla combatants intermingling with the civilian population in the town of Corinto. 


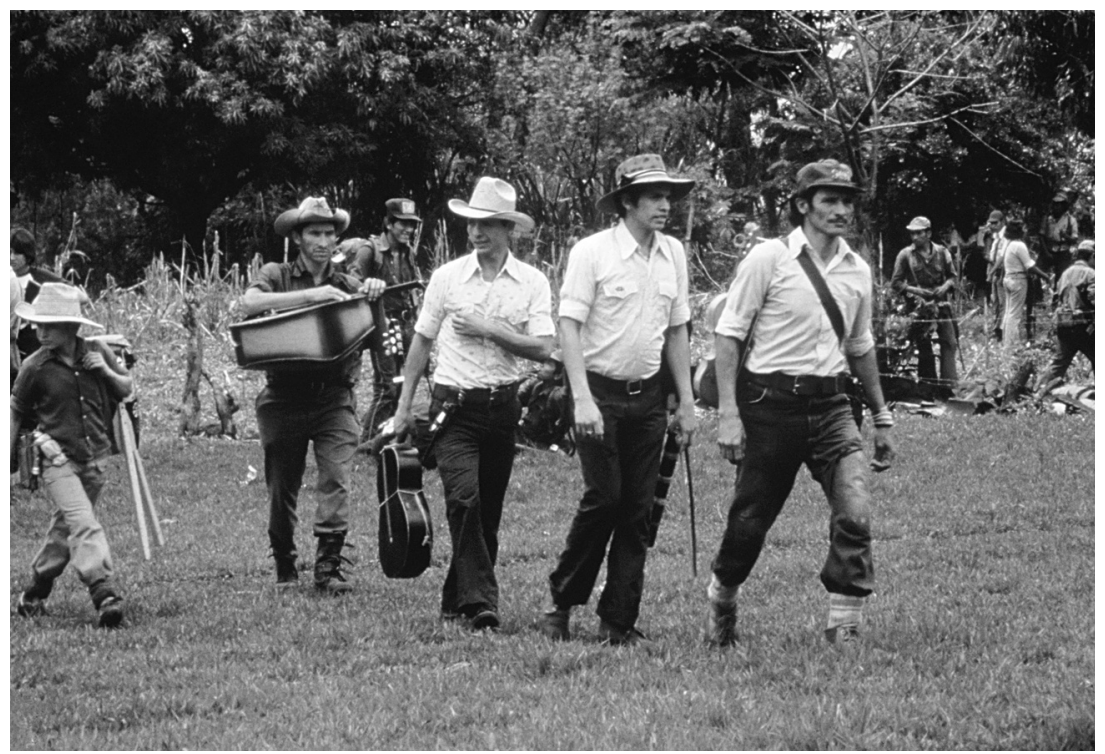

Los Torogoces de Morazán, the guerrillas' band of minstrel musicians and popular historians. Their music was balm for the soul at every dance.

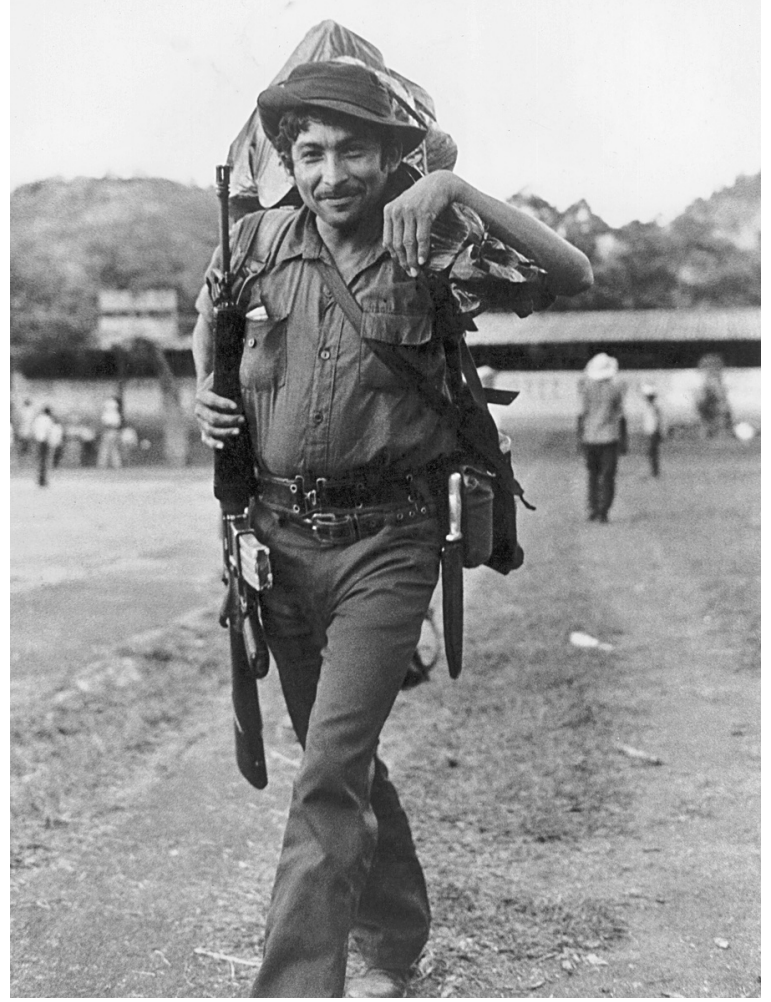

"Jaguaryu," an actor in the guerrillas' popular theater troupe. $\mathrm{He}$ was a close personal friend and one of the last people to die in the war. 


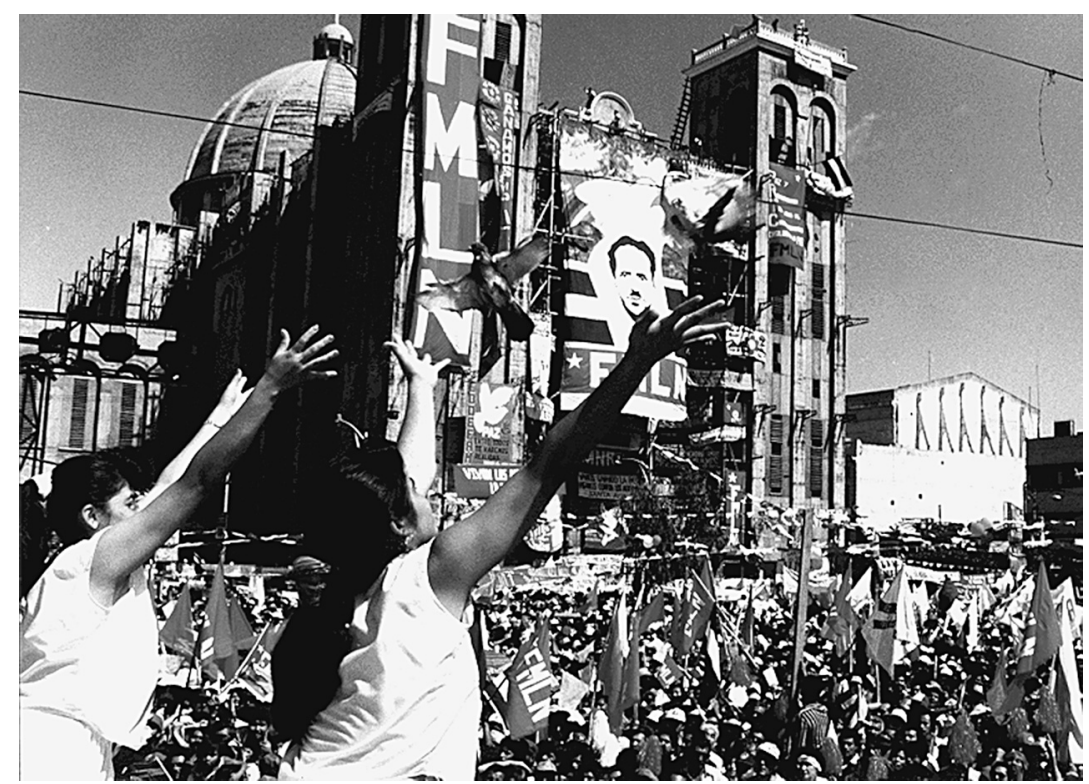

January 16, 1992, atop the cathedral in San Salvador, Santiago makes the victory sign to a helicopter flying overhead. The helicopter is similar to the one that wounded him during a battle in Arambala.

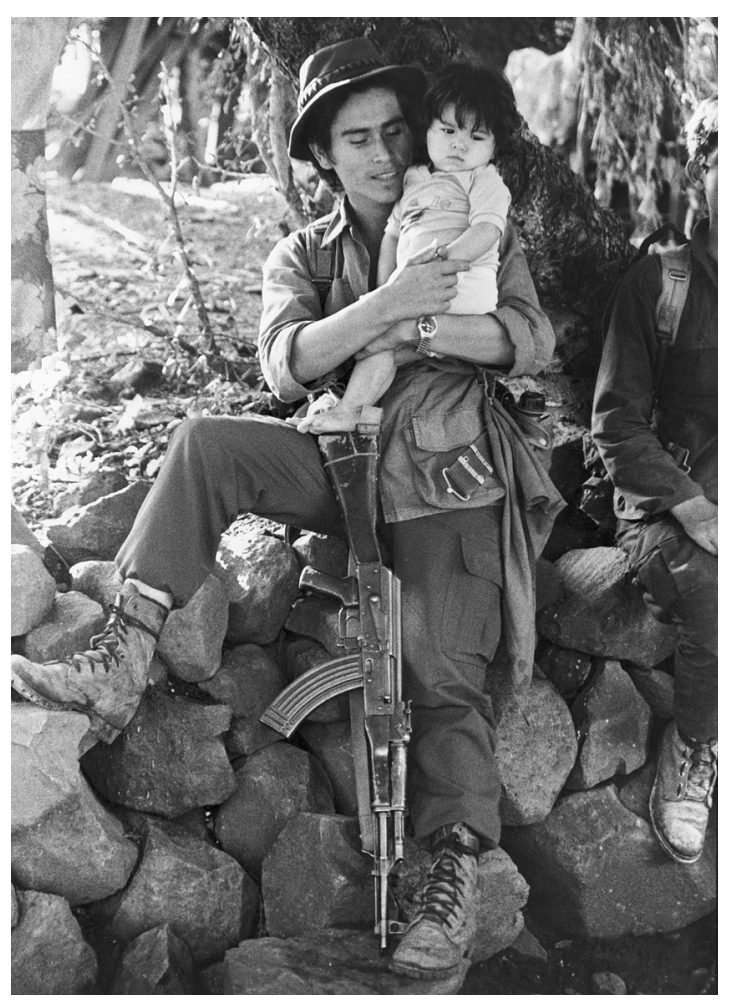

A moment of tenderness in the midst of conflict. 


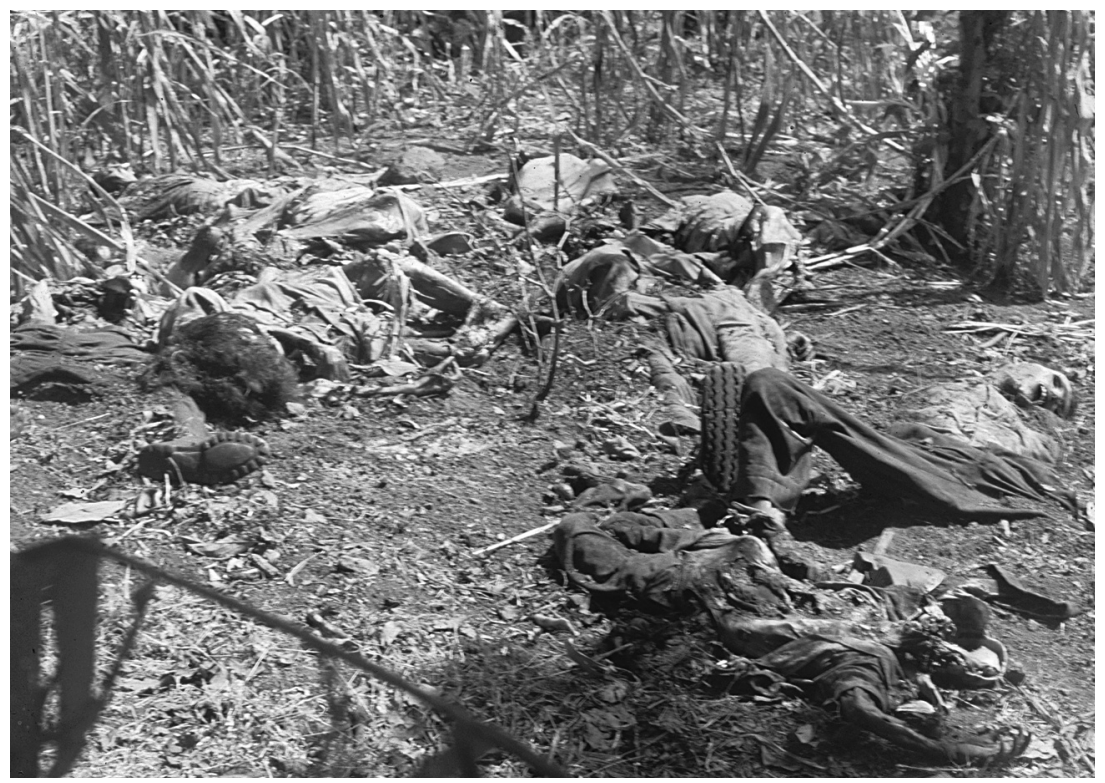

A scene from the massacre at El Mozote, December 1981, captured here by the photojournalist Susan Meiselas.

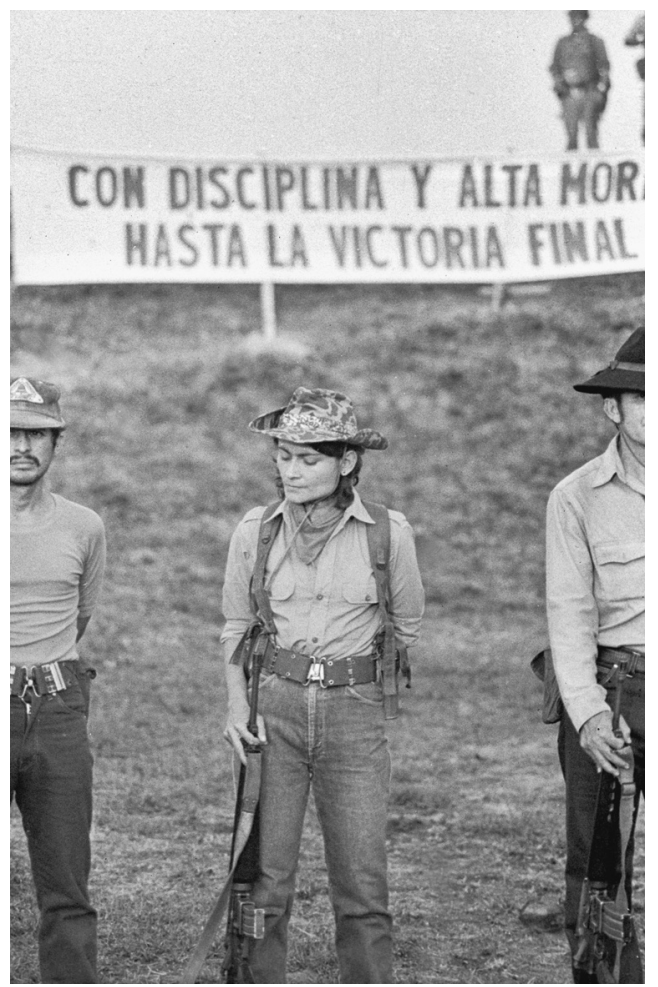

Janeth Samour, who was captured and killed in San Miguel. 


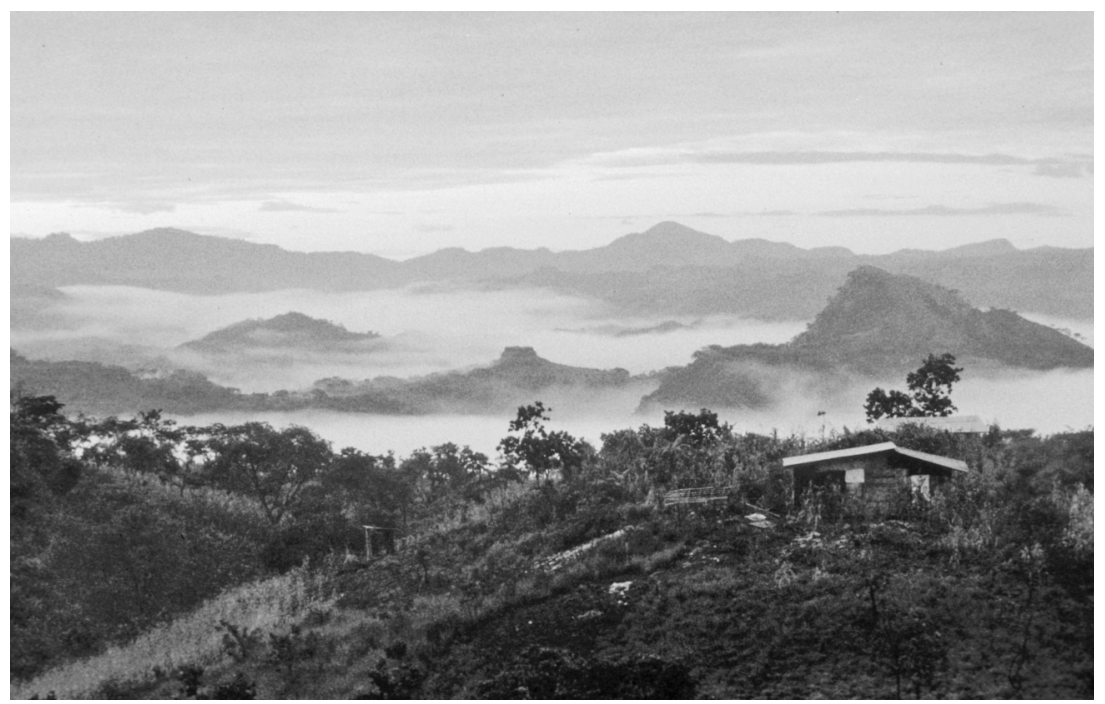

Dawn in Morazán.

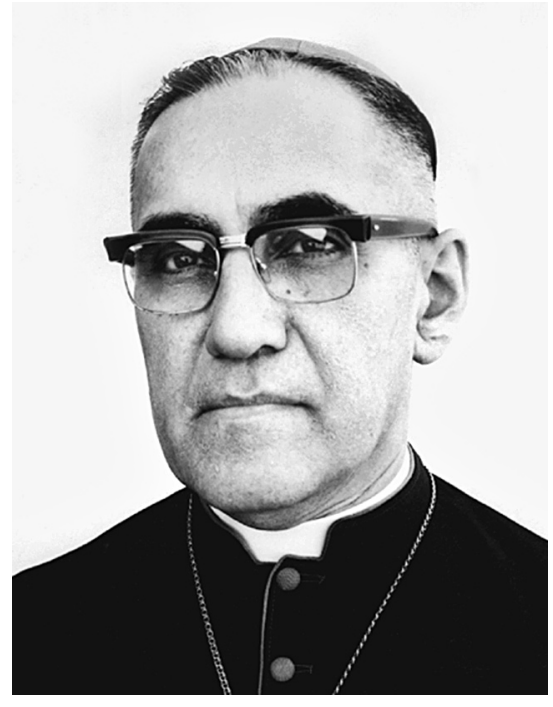

Monsignor Romero, whose photograph was a precious relic that we guarded in our backpacks. 


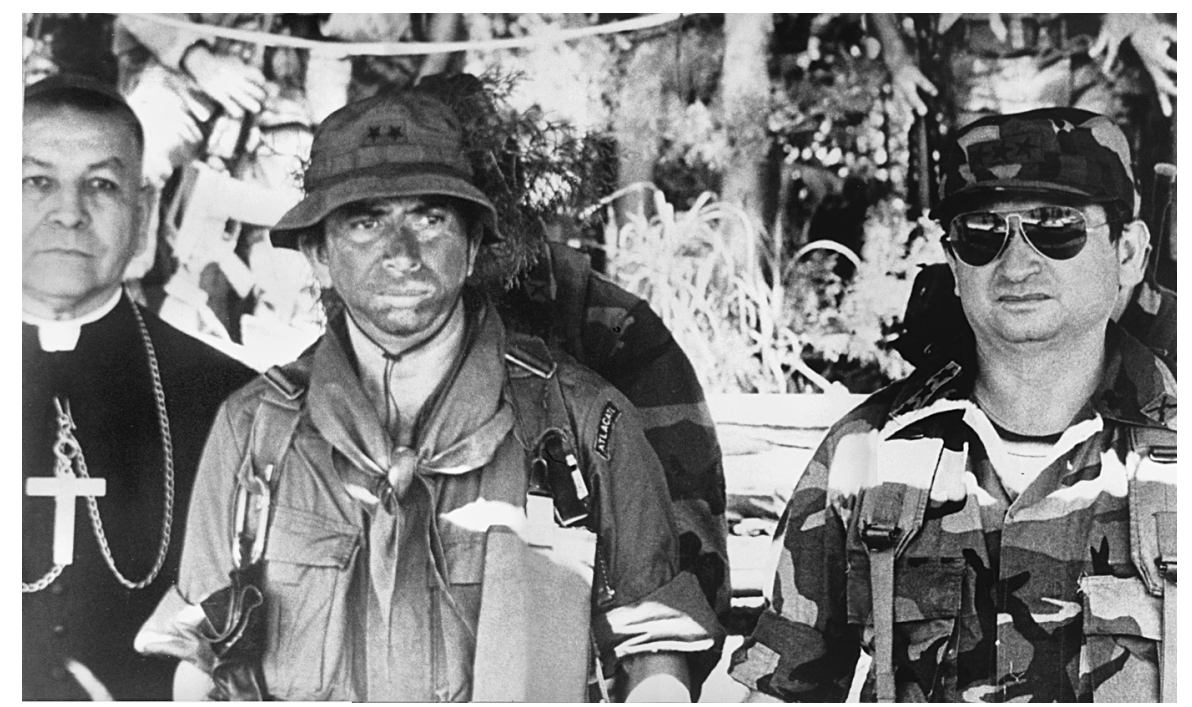

Col. Domingo Monterrosa and Gen. Adolfo Blandón.

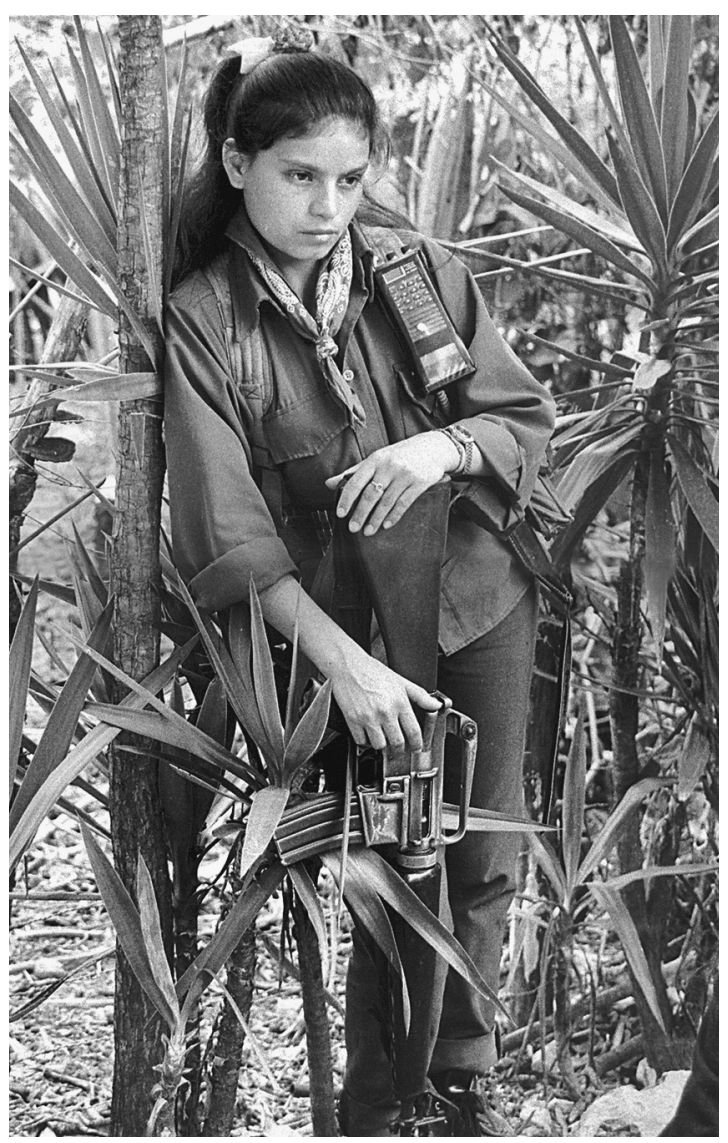

A member of the Radio Venceremos team standing in a field of izotes, the Salvadoran national flower. 
THIS PAGE INTENTIONALLY LEFT BLANK 